Published in final edited form as:

Microbiol Spectr. 2017 July ; 5(4): . doi:10.1128/microbiolspec.FUNK-0048-2016.

\title{
STRESS ADAPTATION
}

\author{
Alistair J.P. Brown ${ }^{1}$, Leah E. Cowen², Antonio Di Pietro ${ }^{3}$, and Janet Quinn ${ }^{4}$ \\ ${ }^{1}$ Aberdeen Fungal Group, University of Aberdeen, Institute of Medical Sciences, Foresterhill, \\ Aberdeen AB25 2ZD, UK \\ ${ }^{2}$ Department of Molecular Genetics, University of Toronto, Toronto, Ontario, Canada M5S 1A8 \\ ${ }^{3}$ Departamento de Genética, Universidad de Córdoba, Campus de Rabanales, Edificio Gregor \\ Mendel C5, 14071 Córdoba, Spain \\ ${ }^{4}$ Institute for Cell and Molecular Biosciences, Newcastle University, Newcastle upon Tyne NE2 \\ $4 \mathrm{HH}, \mathrm{UK}$
}

\section{INTRODUCTION}

Planet earth plays host to an extravagantly diverse range of fungal species. Recent estimates suggest the probable existence of as many as 3 million fungal species (1), and the circa 75,000 of these that have been characterized to date display a wide range of lifestyles. Many fungi occupy specific niches within natural environments, playing essential roles in nutrient scavenging and recycling. Some thrive in close harmony with species from other kingdoms, a superb example being the mycorrhizal fungi, which display mutualistic interactions with plants. Other fungi are pathogenic, causing devastating infections of plants or animals. Indeed, the global threats that fungi pose to human health and food security are being increasingly recognized (2). Fortunately, a relatively small number of fungal species cause infections in humans (circa 400 species are described in the Atlas of Clinical Fungi (3)). Some of these fungi normally occupy environmental niches, but are capable of colonizing and damaging human (or animal) tissues, whereas other fungi appear to be obligately associated with their host.

These diverse fungal niches are dynamic in that they display fluctuations in local parameters such as temperature, water balance, $\mathrm{pH}$ or the levels of particular compounds such as nutrients and reactive oxygen and nitrogen species. These fluctuations are often capable of perturbing cellular homeostasis and causing molecular damage, thereby imposing stress on the fungal cell. Consequently, fungal cells must be able to adapt to these dynamic changes if they are to survive, grow and colonize any niche. This stress adaptation is dependent on three fundamental principles. The first is the ability to detect environmental signals, i.e. the changing inputs from the local environment. The second is the ability to transduce these signals to regulate the cellular processes that mediate the stress adaptation. The third represents the adaptive responses themselves that allow cells to survive the stress. These adaptive processes either counteract or detoxify the initial stress, and repair or remove the molecular damage caused by that stress. These fundamental principles must apply to all fungi. 
Given the elemental nature of environmental stresses, it is not surprising that there are fundamental similarities across the fungal kingdom (and beyond) with regard to the basic cellular processes that mediate adaptation to specific stresses. For example, evolutionary divergent ascomycetes and basidiomycetes induce protein refolding mechanisms in response to changes in temperature $(4,5)$, and the synthesis of antioxidants following exposure to oxidative stresses $(6,7)$. However, different niches exert different evolutionary pressures, and this has led to considerable diversity between fungal species with regard to the robustness of specific stress responses. For example, the yeast Debaryomyces hansenii, which is found in hyper-saline waters, can tolerate higher levels of salt than Saccharomyces cerevisiae (8), which seems to have evolved to grow on fruit and to be disseminated by wasps (9). Also Candida glabrata, which is a fungal pathogen of humans that is relatively resistant to phagocytic killing (10), displays extremely high levels of oxidative stress resistance compared to other yeasts (11). This evolutionary tuning of stress resistance to the local niche has led to some divergence between fungal species in the regulation of the cellular processes that mediate adaptation to some stresses.

This chapter summarizes our current understanding of the mechanisms underlying fungal stress adaptation and the regulation of these responses. We focus on those stresses that have been perceived to be the most relevant and hence have been most studied to date, and the experimentally tractable model fungi in which stress adaptation mechanisms are best characterized. Also, we compare and contrast these outlooks on stress sensing to those from other fungi which have provided fascinating insights into niche-dependent stress adaptation.

\section{ADAPTING TO INDIVIDUAL STRESSES}

\section{FIGURE 1: Overview of Stress Inputs, Pathways and Outputs}

Heat Shock-Temperature modulates diverse facets of biology and disease. Organisms across the tree of life must contend with changes in temperature that can manifest across a multitude of scales, from global climate change, to seasonal environmental change, to abrupt change associated with transitions in environmental niches. For microbial pathogens, temperature can signal the successful infection of a host, and serves as a central cue governing proliferation, developmental programs, and virulence (12). As an example, fever is a ubiquitous response to infection, with elevated febrile temperatures thought to serve as an adaptive host response to restrict microbial proliferation. In a broader context, mammalian endothermy may have evolved as a strategy to minimize infections caused by fungal species, most of which have a diminished capacity to proliferate at elevated temperatures (13). Of the $\sim 3$ million fungal species estimated to exist, less than $0.1 \%$ are able to cause disease in mammals, and this can largely be attributed to most rapidly losing their capacity for growth above ambient temperature (14).

Thermal transitions have a profound impact on fungal development and virulence. For example, virulence of the dimorphic fungal pathogens is controlled by a temperaturedependent change in morphology (15). Blastomyces dermatitidis, Coccidioides immitis, and Histoplasma capsulatum are key species that exemplify the characteristic response to temperature of the dimorphic fungi: these species grow as filamentous molds in the soil in response to ambient temperature and converting to growth as yeast cells in response to host 
temperature upon inhalation of spores into mammalian lungs. The polymorphic fungus, Candida albicans is another fungal pathogen for which temperature induces a dramatic morphological change (16). In contrast to the dimorphic fungi, $C$. albicans proliferates in the yeast form at ambient temperatures, and elevated temperature promotes a transition to filamentous growth. Temperature of $37^{\circ} \mathrm{C}$ is required to enable filamentation in response to diverse cues such as serum, and a further increase in temperature to $39^{\circ} \mathrm{C}$ is sufficient to induce filamentation in the absence of other cues (17). Beyond morphogenesis, temperature exerts a profound influence on diverse aspects of $C$. albicans biology, including mating, phenotypic switching, and drug resistance (17). In addition to the phenotypic consequences of growth at sustained elevated temperatures, fungi also have a profound response to acute but temporary increases in temperature that is referred to as a heat shock response.

Strikingly, a transient heat shock can activate a $C$. albicans transcriptional program that is associated with increased host cell adhesion, host cell damage, and virulence (18).

Fungi have evolved complex molecular machinery and regulatory circuits to respond to the stress induced by sustained or transient responses to elevated temperature, with the heat shock response as one of the most evolutionarily conserved stress responses in nature. Core to the heat shock response is a global arrest of translation elongation, and transcriptional activation of genes encoding heat shock proteins, which include molecular chaperones that promote promoting folding and re-folding (19). In $C$. albicans and the model yeast $S$. cerevisiae, $\sim 10-20 \%$ of genes in the genome are induced in response to heat shock $(20,21)$. This transcriptional response is orchestrated in large part by the heat shock transcription factor Hsf1. In C. albicans, Hsf1 binds to 49 targets constitutively and an additional 55 targets in response to heat shock, with targets enriched for functions in protein folding and entry into the host (18). Hsf1 typically binds at nucleosome-depleted regions in the promoters of target genes, and recognizes three motifs with distinct binding affinities (18). Hsf1 is activated by phosphorylation, and this activation is required for virulence in $C$. albicans $(19,21)$.

Complex functional relationships influence mobilization of cellular responses to thermal stress. Hsf1 promotes the basal expression and thermal induction of genes encoding the molecular chaperone Hsp90 (Figure 1). Hsp90 in turn physically interacts with Hsf1, thereby exerting a repressive effect on activation of the heat shock response (19). As a consequence, perturbation of Hsp90 function by small molecules, mutations, or elevated temperature causes activation of Hsf1 and induction of the heat shock response in the absence of thermal stress. In contrast, Hsp90 is required to mobilize a rapid transcriptional response to thermal stress, such that depletion of Hsp90 causes delayed induction of the transcriptional program induced by heat shock (18). Hsp90 influences transcriptional programs not only via effects on Hsf1, but also by modulating chromatin remodeling, nucleosome removal, and RNA polymerase II stalling (22-24).

As a molecular chaperone, Hsp90 regulates the stability and function of diverse client proteins, which include many core cellular regulators beyond Hsf1. For many client proteins, Hsp90 stabilizes otherwise metastable regulators, thereby enabling their activation in response to stress or other cues $(25,26)$. In the context of thermal adaptation, Hsp90 stabilizes the Hog1 stress activated protein kinase, as well as the mitogen activated protein 
kinases Mkc1 and Cek1 (27-29). In this context, Hsp90 enables signaling required for cell wall remodeling and adaptation to heat shock. Classical genetic screens and chemical genomic approaches to identify mutants that are hypersensitive to Hsp90 inhibition under distinct stress conditions, have provided powerful strategies to identify novel Hsp90 client proteins and key regulators of thermal adaptation $(27,29,30)$.

The circuitry underpinning thermal adaptation can be activated by a remarkable diversity of temperature sensing mechanisms. For example, Hsp90 function is exquisitely sensitive to elevated temperature as the global problems in protein folding that arise for thermal stress create an elevated cellular demand for Hsp90 that exceeds its functional capacity to engage with client proteins (30). In the broader context, DNA, RNA, proteins, and lipids can all serve as thermosensors that sense changes in temperature to initiate crucial cellular responses and developmental programs (12).

Osmotic Stress-Managing changes in water balance represent another fundamental challenge for fungi in most environments. The classic experimental model for this has been the imposition of hyper-osmotic shock through addition of sorbitol or salts such as $\mathrm{NaCl}$ (31). This results in a sudden loss in the intracellular turgor pressure that is required for fungal growth. The fungus must restore its turgor pressure before it can resume growth, and to achieve this, it activates the synthesis and accumulation of intracellular osmolytes such as glycerol, for example (Figure 1).

S. cerevisiae responds to osmotic stress by increasing the flux from glycolysis to glycerol. This is achieved by inducing the genes encoding glycerol-3-phosphate dehydrogenase (GPDI) and glycerol-3-phosphate phosphatase (GPPI). S. cerevisiae can also assimilate glycerol from the growth medium, although this uptake is repressed by glucose (32) which is in contrast to the response of some other yeasts $(33,34)$. However, the intracellular accumulation of glycerol is also dependent on restricting glycerol efflux from the cell through the plasma membrane-based aquaglyceroporin, Fps1 (35). Following the imposition of a hyper-osmotic stress, the intracellular accumulation of glycerol and the restoration of turgor pressure take in the order of 30 minutes (36), after which growth may resume.

This type of response, which involves signalling, gene regulation and subsequent changes in metabolism, is too slow to protect the fungal cell against hypo-osmotic shock. This stress causes the immediate accumulation of water and rapid increases in cell volume which, if not countered quickly, would cause a yeast cell to burst (37). In S. cerevisiae this rapid rise in turgor pressure is alleviated by swift opening of the Fps1 aquaglyceroporin, the activity of which is regulated by protein phosphorylation. Mutations that inactivate Fps1, and hence block rapid glycerol efflux, confer hypo-osmotic stress sensitivity on the yeast cell (38). Clearly, responses to hyper- and hypo-osmotic shocks occur over differing timescales that reflect the relative imminence of potentially irreversible damage to the fungal cell.

Regarding the regulation of osmotic stress responses, the activation of Hog 1 in $S$. cerevisiae has formed the paradigm of osmotic stress activation of fungal SAPKs (39). Like all MAPK modules, the Hog1 MAPK module comprises three tiers of kinases; the MAPKKK(s) at the top of the pathway phosphorylates and activates a downstream MAPKK, which then 
phosphorylates and activates the terminal MAPK. The central importance of this MAPK module in fungal stress sensing is illustrated by its involvement in diverse environmental responses in diverse fungi, which even include light sensing in Aspergillus nidulans (40). In $S$. cerevisiae, two functionally redundant pathways converge at the MAPKK Pbs2 to relay osmotic stress signals to Hog1. These are the Sln1 two-component signalling pathway, and a pathway that contains the SH3-domain-containing Sho1 transmembrane protein. In the first pathway, loss of turgor pressure, induced by high osmolarity, inactivates the transmembrane histidine kinase $\operatorname{Sln} 1$ and thus halts phosphorelay through the phosphorelay protein Ypd1, leading to a rapid dephosphorylation of the Ssk1 response regulator (41). Dephosphorylated Ssk1 activates the MAPKKKs Ssk2/22 in a two-step mechanism (42), leading to phosphorylation and activation of the Pbs2 MAPKK. In the second pathway, the Ste11 MAPKKK phosphorylates Pbs2 when stimulated by osmotic stress signals received from the Sho1 branch of the Hog1 pathway (43). Many proteins are involved in the osmotic stress signalling from Sho1 to Ste11-Pbs2, including Cdc42, Ste20, Cla4, Ste50 and Opy2 (43, 44). Sho1 was originally thought to function as the osmosensor at the top of pathway (45). However, two functionally redundant osmosensensors have since been identified; the mucins, Msb2 and Hkr1 (46). As different signalling mechanisms are employed by Msb2 and $\operatorname{Hkr} 2(47,48)$ the Sho1 branch is now divided into the Hkr1 and Msb2 sub-branches. Whilst Msb2 and other Sho1 branch components also participate in the filamentous growth MAPK pathway, Hkr1 plays a specific role in Hog1 signalling (49) and this is mediated through the newly discovered scaffold protein Ahk1 (50).

As the SAPKs are amongst the most evolutionarily conserved stress signalling proteins in fungi (51), it is remarkable that the mechanisms underlying the osmotic stress regulation of $S$. cerevisiae Hog1 have significantly diverged. For example, in the distantly related model yeast $S z$. pombe, two-component signalling functions to relays $\mathrm{H}_{2} \mathrm{O}_{2}$, but not osmotic, stress signals to the Sty1 SAPK (52), and an orthologue of Sho1 is seemingly absent from the fission yeast genome (51). In C. albicans, although Sho1 pathway components have been identified and characterised they are not required for the relay of osmotic stress signals to Hog1 $(53,54)$. Consistent with this, Hog 1 in $C$. albicans is regulated by a single MAKKK, Ssk2, with the Ste11 MAPKKK - predicted to function downstream of Sho1 - having no obvious role (55). In contrast, the available evidence does support the involvement of twocomponent signalling in the activation of $C$. albicans Hog 1 by osmotic stress, as close homologues of the Sln1-Ypd1-Ssk1 pathway are present in C. albicans, and Hog1 is hyperactivated in cells lacking $\operatorname{Sin} 1$ (54). However, the observation that osmotic stressinduced Hog1 activation is not notably impaired in cells lacking the Ssk1 response regulator (56) suggests the presence of a novel osmotic stress sensing pathway in this fungal pathogen. In certain $C$. glabrata isolates, only the Sho1 branch functions to relay osmotic stress signals to Hog 1 . This is due to a truncated $s s k 2$ allele which prevents signalling through the $\operatorname{Sn} 1$ branch (57). Intriguingly, gain of function mutations have been identified in the related Ssk2 MAPKKK in Cryptococcus neoformans (58), which are responsible for high basal levels of Hog1 activation in serotype A strains (59).

Hog 1 has been shown to play a central role in the regulation of osmoadaptation in $S$. cerevisiae. This MAPK regulates glycerol accumulation of glycerol via transcriptional activation of GPD1 and GPP1 in response to osmotic stress via the transcription factors 
Hot1, Msn2 and Msn4 (60), and by controlling the activity of the Fps1 acquaglyceroporin (61). It should be noted that additional TORC2/Ypk1-dependent signalling mechanisms do contribute to the regulation of Fps1 and hence to survival in the face of hyper-osmotic stress (38). However, Hog 1 also mediates the transient delay in cell cycle progression following hyper-osmotic shock by phosphorylation of Sic1 and Hsl1, and by down-regulating G1 and G2 cyclins (62). Once osmo-adaptation is achieved, the yeast cell has essentially achieved a new homeostatic state in which turgor pressure has been restored in the face of the external osmotic conditions (63). Consequently, the input signal has been dampened, Hog 1 becomes de-activated, the block to cell cycle progression is released, and growth can resume.

Oxidative Stress-Reactive oxygen species (ROS) are highly damaging, reduced forms of oxygen, which include the superoxide anion $\mathrm{O}_{2}{ }^{\circ}$, hydrogen peroxide $\left(\mathrm{H}_{2} \mathrm{O}_{2}\right)$, and the hydroxyl radicle $(\mathrm{OH})$. These reactive molecules damage proteins, DNA, and lipids, and can trigger programmed cell death (64). All fungi that grow aerobically are exposed to superoxide anions generated as a by-product of aerobic respiration in the mitochondria (65). Environmental fungi are also exposed to ROS generated following exposure to UV light or to drugs/xenobiotics found in the environment (64). In addition, pathogenic fungi are exposed to superoxide and hydrogen peroxide ROS which are generated by plant (66) or animal (67) host defence systems as a major antimicrobial defence mechanism.

Significantly, other toxic chemicals are subsequently derived from the host-generated ROS (67).

Oxidative stress occurs when the levels of ROS exceed the antioxidant capacity of the cell which functions to maintain the intracellular redox environment in a reduced state. In response to oxidative stress, fungal cells mount a wide range of defence and repair strategies. One well-characterized and conserved response involves the rapid induction of mRNAs that encode oxidative stress detoxification and repair proteins (Figure 1). Transcript profiling studies indicate that a set of core anti-oxidant genes are induced in fungi following exposure to $\mathrm{H}_{2} \mathrm{O}_{2}(20,68-72)$. These include catalase (CAT1), glutathione peroxidase $(G P X)$, and superoxide dismutase $(S O D)$ - antioxidant encoding genes, in addition to genes encoding components of the glutathione/glutaredoxin (GSH1, TTR1) and thioredoxin (TSA1, TRX1, TRRI) systems. An additional and very rapid response to oxidative stress, that precedes transcriptional activation, is the dynamic redirection of the metabolic flux from glycolysis to the pentose phosphate pathway. This metabolic switch is triggered by the oxidation and inactivation of the glycolytic enzyme GAPDH, which functions to promote the generation of reducing power in the form of NADPH (73). Yeast cells also transiently delay cell cycle progression following exposure to ROS to allow DNA damage repair. For example, $\mathrm{H}_{2} \mathrm{O}_{2}$ causes a $\mathrm{G} 2$ cell cycle arrest in $S$. cerevisiae by activating the Rad53 DNA damage checkpoint (74). For more details on activation of DNA damage checkpoints in $S$. cerevisiae the readers are directed to this recent excellent review (75). In the pathogenic fungus, $C$. albicans, exposure to $\mathrm{H}_{2} \mathrm{O}_{2}$ also triggers a $\mathrm{Rad} 53$-mediated cell cycle arrest. Interestingly, in this fungus, such genotoxic-induced cell cycle arrest promotes the formation of a filamentous hyperpolarized bud growth form $(76,77)$.

Orthologues of transcription factors that are vital for oxidative stress-responsive gene induction in S. cerevisiae, the AP-1-like bZip factor Yap1 and the Skn7 response regulator, 
have now been studied in many fungi (67). The elegant mechanism underlying activation of S. cerevisiae Yap1 is well characterized. Following exposure to $\mathrm{H}_{2} \mathrm{O}_{2}$, specific cysteine residues located within two distinct two cysteine-rich domains (CRDs) become rapidly oxidised (78). This oxidation event, which requires the thiol peroxidase Gpx3 (79), and the Yap1 binding protein Ybp1 (80), triggers a conformational change within Yap1 that masks a nuclear export sequence (81). Consequently, Yap1 accumulates in the nucleus resulting in the induction of Yap1-dependent genes (79). In the human fungal pathogen, C. albicans, Cap1 oxidation is similarly regulated by Gpx3 and Ybp1 (82). However, in the model yeast $S z$. pombe, Pap1 oxidation depends instead on the 2-Cys peroxiredoxin Tpx1 (83), and in the fungal symbiont Epichloe fustucae redox regulation of the analogous YapA factor is independent of both Gpx3 and Tpx1 (84). Thus multiple mechanisms may exist to regulate the oxidation of fungal AP-1-like factors. Interestingly, AP-1-like factors have been found to be dispensable for the virulence of the human fungal pathogens Aspergillus fumigatus (85), Cr. neoformans (86), and $C$. albicans $(82,87)$, but are required for the virulence of a number of plant pathogens (88-90).

In $S$. cerevisiae, Yap1 collaborates with Skn7 to regulate many oxidative stress-response genes and this may be conserved, as similar findings have been reported in C. glabrata (91), and $S z$. pombe (92). Little is known about Skn7 activation following oxidative stress, but a study has reported a DNA-independent interaction between Yap1 and Skn7 in S. cerevisiae (93), and in C. glabrata Yap1 and Skn7 cooperatively bind to the upstream region of core oxidative stress genes (91). In $S z$. pombe, a role for two-component mediated phosphorylation of the $\mathrm{Skn} 7$ homologue in responses to high levels of $\mathrm{H}_{2} \mathrm{O}_{2}$ stress has been uncovered (94). A recent review summarizes the functions of Skn7 and roles in fungal virulence (95).

In addition to Yap1 and Skn7, are the bZip factors of the ATF/CREB family. The best characterized is the Atf1 transcription factor in the model yeast $S z$. pombe. In response to oxidative stress Atf1 is hyper-phosphorylated by the Sty1 SAPK (96). This stabilizes this transcription factor which is vital for its function in oxidative stress-induced gene expression $(97,98)$. Analogous transcription factors shown to play roles in oxidative stress mediated gene expression include Atf1 in Cr. neoformans (99), Moatf1 in Magnaporthe oryzae (100), and AtfA in A. nidulans and A. fumigatus $(101,102)$. Moreover, there is emerging evidence to support the general concept that such transcription factors are targets of fungal SAPK pathways $(102,103)$.

Although the Hog1 SAPK in $S$. cerevisiae is dispensable for oxidative stress responses (20, 104), homologues play important roles in oxidative stress tolerance in many other fungi. These include the model yeast $S z$. pombe (105), the filamentous fungus $A$. nidulans (102), a number of human pathogenic fungi including $C$. albicans (106), Cr. neoformans (59), $A$. fumigatus (107), and the plant pathogens Bipolaris oryzae (108) and Fusarium graminearum (109). The Sty1 pathway in the model yeast, $S z$. pombe, has provided key insight into the oxidative stress mediated activation of such pathways. Sty1 is robustly phosphorylated in response to oxidative stress and plays a major role in the regulation of the oxidative-stress induced transcriptome (92). In $S z$. pombe, a two-component signalling system operates to relay $\mathrm{H}_{2} \mathrm{O}_{2}$, and not osmotic, stress signals to the Sty1 SAPK module. The Mak2 and Mak3 
histidine kinases contain redox sensing PAS and GAF domains, that are essential for the relay of $\mathrm{H}_{2} \mathrm{O}_{2}$ signals to $\mathrm{Sty} 1$ (94). In addition, protein oxidation also regulates the $\mathrm{H}_{2} \mathrm{O}_{2}$ induced activation of Sty1. The redox sensitive peroxiredoxin enzyme Tpx1 is essential for $\mathrm{H}_{2} \mathrm{O}_{2}$-mediated Sty 1 activation and, as intermolecular disulphide bonds are formed between conserved cysteine residues in Sty1 and Tpx1 following $\mathrm{H}_{2} \mathrm{O}_{2}$ stress, it appears that Tpx 1 may regulate Sty 1 function directly (110). Mechanisms underlying $\mathrm{H}_{2} \mathrm{O}_{2}$-mediated SAPK activation have also been explored in $C$. albicans. $C$. albicans $\mathrm{Hog} 1$ is robustly activated following exposure to $\mathrm{H}_{2} \mathrm{O}_{2}$ (71), and hog $1 \Delta$ cells are sensitive to a range of ROS (106, 111), despite a limited transcription role (71). Similar to that in $S z$. pombe, oxidative stressinduced Hog 1 phosphorylation is drastically reduced in cells lacking the Ssk1 response regulator (56), although no similar roles have been found for the upstream histidine kinases $(54,112)$. Both the redox sensitive peroxiredoxin Tsa1, and thioredoxin Trx1, enzymes are vital for $\mathrm{H}_{2} \mathrm{O}_{2}$-induced $\mathrm{Hog} 1$ activation in $C$. albicans (76). Thus protein oxidation appears to be an important mediator of both $C$. albicans and $S z$. pombe SAPK activation following oxidative stress. Mechanistic details regarding oxidative-stress mediated SAPK activation in other fungi are lacking, although in A. nidulans it has been shown that the SskA response regulator is essential for oxidative stress-induced activation of the SakA SAPK (113).

Nitrosative Stress-Fungal cells experience nitrosative stress when they are exposed to relatively high levels of reactive nitrogen species (RNS). These RNS include nitric oxide $(\cdot \mathrm{NO})$ and its derivatives peroxynitrite $\left(\mathrm{ONOO}^{-}\right.$, which formed by the reaction of nitric oxide with superoxide, $\left.\mathrm{O}_{2}{ }^{-}\right)$, nitrite $\left(\mathrm{NO}_{2}^{-}\right)$, nitrogen dioxide $\left(\cdot \mathrm{NO}_{2}^{-}\right)$and nitrate $\left(\mathrm{NO}_{3}{ }^{-}\right)$. Fungi are confronted by RNS in the soil, as well as in mammalian hosts where these reactive molecules are components of the phagocytic armoury used to combat microbial infection (114-116). Therefore, the protective responses of fungal pathogens against nitrosative stress are important for pathogenicity and have been examined in some detail, for example in $C$. albicans and $C r$. neoformans $(117,118)$. In contrast, for plant pathogens such as Blumeria graminis, Botrytis cinerea and M. oryzae, NO has been shown to promote the spread of infection in plant hosts. These effects might be mediated by the action of NO as a developmental signal (119-121), but could also be due to the influence of fungus-derived NO upon the behaviour of the plant host (122).

Excess RNS damage proteins by reacting with thiols, metal centres and tyrosine residues. Fungi protect themselves by buffering RNS with antioxidants such as glutathione, and by inducing mechanisms to detoxify the RNS and repair the damage they cause. NO reacts with glutathione (GSH) to generate S-nitrosoglutathione (GSNO). To restore redox homeostasis, fungi recycle this GSNO to GSH, via glutathione disulphide (GSSG). This is achieved through the evolutionarily conserved enzymes S-nitrosoglutathione reductase (GSNOR: Fdh3) and glutathione reductase (Glr1) (123-125). NO detoxification to nitrate is mediated by nitric oxide oxidoreductases (e.g. S. cerevisiae Yhb1), which are conserved enzymes that are members of the flavohaemoglobin family (126).

While the processes that protect against RNS are evolutionarily conserved, the regulatory mechanisms that induce these processes in response to RNS appear to have diverged. For example, while RNS exposure triggers global changes in the expression profiles of $S$. cerevisiae and $C$. albicans that include the induction of Yhb1 and glutathione synthesis (117, 
127), seemingly unrelated transcription factors drive these changes. In S. cerevisiae, YHB1 expression is induced by the transcription factor Fzf1 (127) (Figure 1), whereas Cta4 activates $Y H B 1$ in $C$. albicans (128). Nevertheless, the outcomes are similar: these transcription factors both promote $\mathrm{Yhb} 1$ and glutathione expression, and hence nitrosative stress resistance in these fungi. For the fungal pathogen, $C$. albicans, the deletion of $Y H B 1$ or its activator $C T A 4$ attenuates virulence slightly $(117,128,129)$. Similarly, inactivation of the nitric oxide oxidoreductase (Fhb1) or the GSNOR (Gno1) in Cr. neoformans attenuates the virulence of this pathogen (130). NO production by the host does not seem to be a major factor in limiting fungal virulence (117). Nevertheless, the available data suggest that RNS detoxification does contribute to fungal virulence.

Cell Wall Stress-The fungal cell wall is a dynamic structure that is continually remodeled during cell growth and division. The cell wall represents $\sim 25 \%$ of the yeast cell dry weight, underscoring the extensive metabolic commitment to support this elaborate structure, which provides the key interface for mediating interactions with the environment (131). Fungal cell wall architecture involves layers of polysaccharides and glycoproteins, although the specific composition varies across species. Typically, a matrix of chitin, $\beta-1,3-$ glucan and $\beta$-1,6-glucan constitute the core inner layer, with mannans and other mixed glycans and glycoproteins prevalent in the outer layer. Cell walls provide crucial protection against changes in external osmotic potential, and can confer resistance to infection and to degradation by soil predators such as amoebae and protists. These adaptive advantages may contribute to the emergence and maintenance of cell walls in the fungal kingdom (132). Cell walls serve not only as a protective shell, but also as a means to modulate immune recognition. Fungal cell wall glycans, glycolipids, and proteins that are absent from mammals activate a wealth of immune recognition mechanisms, and the dynamic exposure of such pathogen-associated molecular patterns can serve to modulate immune recognition (133). As a consequence, perturbation of fungal cell wall architecture can potentiate immune responses and induce lethal cell wall stress. Molecules that potently inhibit fungal cell wall biosynthesis have been elaborated in nature as with the echinocandins, and exploited in modern medicine with semi-synthetic derivatives now a front-line treatment for fungal infections (134).

Fungi have evolved complex cellular circuitry to sense and respond to cell wall stress. Although details vary among fungi, the core architecture is broadly conserved. Cell wall stress is typically sensed at the plasma membrane via cell surface sensors, which include Wsc1, Wsc2, Wsc3, Mid2, and Mt11 in S. cerevisiae (131). This stimulates nucleotide exchange on the small G-protein Rho1, which orchestrates cell wall integrity signaling. Downstream effectors of Rho1 coordinate synthesis of $\beta$-glucans, transcriptional control of cell wall genes, polarization of the actin cytoskeleton, and targeting of secretory vesicles. The most well established pathway through which cell wall integrity signals are transduced from Rho1 is the mitogen activated protein kinase cascade that includes Pkc1, Bck1, Mkk1/2, and Mpk1/Slt2 in S. cerevisiae (17). Although this cascade provides a powerful mechanism to amplify cell surface signals and coordinate highly sensitive responses, additional robustness is integral to ensure maintenance of cell wall physiology and is achieved by complex genetic interaction networks. These networks can enable compensatory 
responses to cell wall perturbations. For example, activation of chitin synthesis suppresses the antifungal activity of echinocandins (135-137), which inhibit biosynthesis of $\beta-1,3-$ glucan. The highly connected genetic networks that control cell wall stress response circuitry can be activated by diverse environmental stresses, providing a powerful strategy to rapidly mobilize protective mechanisms.

Environmentally contingent hubs of cellular signaling are crucial for orchestrating cell wall stress responses. An excellent example is the molecular chaperone Hsp90. Hsp90 modulates the stability and function of diverse regulators of cellular signaling, thereby enabling responses to a myriad of stresses, including perturbation of the cell wall $(29,138,139)$ (Figure 1). Hsp90 enables responses to cell wall stress at least in part by modulating cell wall integrity signaling. Hsp90 stabilizes the terminal mitogen activated protein kinase in the cell wall integrity pathway, Slt2 in S. cerevisiae and Mkc1 in C. albicans (140-142). Hsp90 also stabilizes an additional mitogen activated protein kinase that is implicated in cell wall remodeling, Cek1 (29). Compromise of Hsp90 function leads to depletion of these kinases and hypersensitivity to cell wall stress. Additional Hsp90 client proteins important for cell wall remodeling are the protein phosphatase calcineurin and kinase Hog1. Signaling through the cell wall integrity pathway, Hog 1 , and calcineurin coordinately regulates the synthesis of chitin in response to stress induced by perturbation of the cell wall or cell membrane (143). Chitin levels are dramatically increased in response to echinocandins, which provides protection that enables cells to cope with cell wall damage (135). Cell damage induced by various genetic or environmental insults can also be buffered by activation of other core cellular signaling pathways, such as the cyclic AMP protein kinase A cascade (17). Although the molecular details have been explored in the greatest depths in $S$. cerevisiae, many conserved principles of coordinate control of cell wall stress response are emerging from studies in diverse fungi (144-147).

There is broad therapeutic potential of targeting core regulators of cell wall stress responses as a strategy to enhance the efficacy of antifungal drugs that target the cell wall, as with the echinocandins. This potential is illustrated by the discovery that inhibition of Hsp90 of calcineurin enhances the efficacy of echinocandins against diverse fungal pathogens in multiple models of infection $(138,145,148)$. The therapeutic challenge of exploiting these conserved eukaryotic cellular regulators as targets for antifungal drug development lies in development of molecules that can distinguish the pathogen from the host. Achieving this goal can be facilitated by structure-guided drug design (149). As a complementary approach to targeting regulators of cell wall stress response, systematic screens for molecules that potentiate the activity of echinocandins provides a powerful strategy to enhance the efficacy of our limited arsenal of antifungal drugs and thwart the emergence of drug resistance (150).

pH stress-Alkaline $\mathrm{pH}$ imposes a number of stresses on fungi. One of the most significant relates to nutrient acquisition. At high extracellular $\mathrm{pH}$, the establishment of electrochemical gradients across the plasma membrane for nutrient transport and ATP synthesis is more difficult (151). Moreover, the solubility and biological availability of essential elements such as iron is dramatically reduced at high $\mathrm{pH}$. The finding that addition of micromolar concentrations of copper or iron ions significantly improves the growth of $S$. 
cerevisiae at high $\mathrm{pH}$ suggests that these two elements are limiting factors for growth under alkaline $\mathrm{pH}$ conditions (152).

An important aspect of $\mathrm{pH}$ regulation is the ability to regulate gene expression in response to ambient $\mathrm{pH}$, which allows fungi to synthesize the environmentally appropriate gene products, particularly secreted proteins. This ability has practical implications, for example in the production of secondary metabolites or for fungal pathogenicity on plant and animal hosts $(153,154)$. Environmental $\mathrm{pH}$ also has profound effects on fungal development. For example, in $C$. albicans a shift from acidic to neutral-alkaline $\mathrm{pH}$ promotes the transition from yeast to filamentous growth ((153).

The best known alkaline pH-responsive signal transduction mechanism in fungi is the Pal/Rim pathway (Figure 1). This pathway has been extensively studied in A. nidulans (Pal) and $S$. cerevisiae (Rim). In $A$. nidulans, the Pal pathway sequentially involves the proteins PalH, PalI, PalF, PalC, PalA and PalB. Moreover, the pathway encompasses a number of coopted components of the multivesicular body (MVB) and ESCRTs (endosomal sorting complexes required for transport) (154). Activation of the pathway by alkaline $\mathrm{pH}$ leads to proteolytic activation of the zinc finger transcription factor PacC/Rim101 $(155,156)$. PacC undergoes two successive $\mathrm{C}$-terminal proteolytic cleavages from the full length $72-\mathrm{kDa}$ to the processed $27-\mathrm{kDa}$ active form, the first of which is $\mathrm{pH}$-dependent and carried out by the signalling protease PalB (154).

$\mathrm{PalH} / \mathrm{Rim} 21$, a seven-transmembrane domain plasma membrane protein, is thought to function as $\mathrm{pH}$ receptor. PalH forms a complex with the arrestin-like protein PalF/Rim8, which is ubiquitinated in an alkaline pH-dependent manner and recruits ESCRT-I Vps23, thereby creating multiple docking sites for the downstream signalling components (157160).

An open question is how PalH/Rim21 senses alkaline ambient $\mathrm{pH}$. The membrane potential of the yeast plasma membrane is mainly generated by differences in proton concentration between the inside and outside of the cell. External alkalization therefore leads to impaired phospholipid flipping and plasma membrane depolarization by collapsing the proton electrochemical gradient. Interestingly, it was shown that the Rim101 pathway in yeast can be activated in a $\mathrm{pH}$-independent manner by either protonophore treatment or depletion of phosphatidylserine in the inner leaflet of the plasma membrane, both of which cause plasma membrane depolarization similar to external alkalization. This activation is dependent on Rim21, suggesting that plasma membrane depolarization is a key signal sensed by Rim21 (160). Moreover, a recent study suggests that alterations in lipid asymmetry cause changes in lipid composition and local charge on the inner leaflet, leading to dissociation of the Rim21 complex from the plasma membrane and recruitment of downstream proteins (161). Thus Rim21 senses external alkalization, as well as altered lipid asymmetry. It was proposed that Rim21 uses its flexible C-terminal cytosolic tail like an antenna to monitor the status of membrane lipid asymmetry (161).

To achieve infection, pathogenic fungi must adapt to wide variations in the ambient $\mathrm{pH}$ of host tissues, which, in humans, can vary from 2 to $>8$ depending on the niche. Early studies 
in $C$. albicans revealed that genes encoding two functionally redundant cell wall $\beta$ glycosidases, $P H R 1$ and $P H R 2$, display divergent $\mathrm{pH}$-dependent expression patterns and virulence functions in cell wall remodelling. While $P H R 1$ is expressed preferentially at neutral-alkaline $\mathrm{pH}$ and is required for systemic infection, $P H R 2$ is expressed preferentially at acidic $\mathrm{pH}$ and is required for vaginal infection (162). These $\mathrm{pH}$-dependent expression patterns are dependent on PacC/Rim signalling (163). More recently, multiple roles for the PacC/Rim pathway during human colonization and infection have been established in $C$. albicans, including filamentation, adhesion to host cells, tissue invasion, iron acquisition and protease secretion (153). The role of PacC/Rim101 in mammalian infection is conserved in filamentous ascomycetes such as Fusarium oxysporum and A. fumigatus $(164,165)$. In the basidiomycete human pathogen $C r$. neoformans the RIM pathway is also involved in pathogenicity (166), although the function of PalH/Rim21 appears to be carried out by a distinct membrane protein (167).

Alkaline $\mathrm{pH}$ signalling is also of relevance in other fungus-host interactions. For example, deletion of PacC in the nematophagous fungus Clonostachys rosea and the insect pathogen Metarrizium robertsii results in attenuated virulence $(168,169)$. In plant pathogens, the role of PacC in virulence varies depending on the pathogen-host system. While it contributes to virulence in the rice blast fungus $M$. oryzae and the fruit pathogen Penicillium expansum, it appears to function as a negative virulence regulator in the vascular wilt fungus $F$. oxysporum (170-172).

Besides the Pal/Rim pathway, additional cell signalling pathways function in fungal adaptation to neutral/alkaline $\mathrm{pH}$. The calcium-dependent protein phosphatase calcineurin and its downstream transcription factor $\mathrm{Crz} 1$ are required for growth at alkaline $\mathrm{pH}$ and for fungal virulence on animal and plant hosts (173-177). Crz1 also mediates tolerance to high cation concentrations (178). Mds3, a negative regulator of the TOR pathway, promotes adaptation to neutral/alkaline $\mathrm{pH}$ as well as virulence-related morphogenesis in $C$. albicans (179). Moreover, mutations in the cell wall integrity MAPK cascade confer sensitivity to alkaline stress, and alkalinization results in rapid and transient phosphorylation of the Slt2 MAPK in $S$. cerevisiae (180). This suggests that alkaline $\mathrm{pH}$ stress profoundly affects the composition of the fungal cell wall.

Recently, a novel signalling pathway was identified which is required for resistance to alkaline $\mathrm{pH}$ and cation stress in A. nidulans (177). This pathway, which appears to be specific to filamentous fungi, is defined by the transcription factor SltA and the serine protease SltB. Activation of SltA requires proteolytic cleavage and removal of the Nterminal domain by SltB and phosphorylation of the functional C-terminal moiety (181). Interestingly, while the SltA pathway is conserved in filamentous fungal pathogens, its role in infection remains to be determined.

Weak Acid Stress Response-The weak acid stress response has been largely studied in the context of food spoilage, but it is likely to be highly relevant to environmental and pathogenic fungi that occupy acidic niches or that are exposed to phagocytic attack. Weak organic acids such as acetic, propionic, sorbic and benzoic acid impose stress on fungal cells when the environmental $\mathrm{pH}$ lies below the $\mathrm{p} K_{\mathrm{a}}$ of the acid in question (i.e. below $\mathrm{pH} 4.8$ for 
acetic acid). Below its $\mathrm{p} K_{\mathrm{a}}$, a weak acid is in its associated nonpolar form and is better able to cross the plasma membrane. Acetic acid enters the $S$. cerevisiae cell via the aquaglyceroporin Fps1, whereas propionic, sorbic and benzoic acid appear to diffuse passively across the plasma membrane (182). Once they enter the higher $\mathrm{pH}$ of the cytoplasm they dissociate into the free acid anion and proton $\left(\mathrm{H}^{+}\right)$. The equilibrium of this reaction drives the accumulation of the acid anion and protons, and consequently acidification of the cytoplasm. Weak acid stress is imposed partly by this cytoplasmic acidification, and partly by the accumulation of the organic anion, which can impose toxic effects on yeasts and moulds $(183,184)$. For example, sorbic acid appears to exert membrane-active antimicrobial effects in $S$. cerevisiae (183).

Fungal cells respond to weak acid stress by attempting to maintain their intracellular $\mathrm{pH}$ and by exporting the organic anion. In $S$. cerevisiae these tasks are executed by Pma1 and Pdr12, respectively $(185,186)$. Pma1 is the plasma membrane $\mathrm{H}^{+}$-ATPase proton pump. This pump is essential for growth and for the restoration of cytoplasmic $\mathrm{pH}$, which is an energydemanding process (187). Pdr12 is an ATP binding cassette transporter that mediates efflux of the organic anion from the yeast cell. Pdr12 is also important for the restoration of cytoplasmic $\mathrm{pH}$ during sorbic and benzoic acid stress (188).

In $S$. cerevisiae resistance to acetic acid stress is dependent on Hog 1 signalling. Hog 1 downregulates the Fps1 aquaglyceroporin, thereby reducing acetate accumulation (182), and activates the Haal transcriptional regulon which includes genes encoding membrane stress proteins (189). Meanwhile resistance to propionic, sorbic and benzoic acids depends on the induction of PDR12 (185) via the transcription factor War1 $(190,191)$. War1 is potentially regulated by direct binding of the organic anion, thereby precluding a requirement for upstream signaling.

Analogous regulatory mechanisms appear to exist in some yeasts. For example, Hog 1 mediates sorbic acid resistance in C. glabrata (192), and resistance to this weak acid in $C$. albicans is dependent upon a War1 orthologue (193) as well as the Msn2/Msn4-like transcription factor Mnl1 (194). However, alternative mechanisms seem to mediate weak acid stress resistance in other yeasts, most notably the food spoilage organism, Zygosaccharomyces bailii, which displays high levels of weak acid stress resistance. In this species, survival in the face of weak acid stress is appears to be dependent on population heterogeneity: a proportion of cells that display low cytoplasmic $\mathrm{pH}$, and therefore reduced weak acid accumulation, give rise to a population of resistant cells (195). Rather than inducing a Pdr12-like weak acid exporter, $Z$. bailii degrades sorbate and benzoate, exploiting them as a carbon source (185).

Core Stress Response-In the preceding sections we have discussed fungal responses to individual stresses. Here we describe how exposure to different types of stress can lead to similar responses via what has been termed the Core Stress Response (CSR). Genome-wide transcript profiling studies first revealed the existence of CSRs in the model yeasts $S$. cerevisiae (20,68) and $S z$. pombe (69), in the pathogenic fungus $C$. glabrata (72), and to a lesser extent in $C$. albicans $(70,71)$. Formally, the CSR describes a set of genes that are commonly regulated in response to diverse types of stress (Figure 2). 
In $S$. cerevisiae, between 200 and 300 genes were found to be up regulated in response to diverse stresses including heat shock, osmotic stress, oxidative stresses, increases or decreases in $\mathrm{pH}$, and amino acid starvation $(20,68)$. In addition, between 300 and 600 genes were commonly down regulated following exposure to these diverse stress treatments (20, 68). Thus in $S$. cerevisiae the CSR involves approximately $10-14 \%$ of the yeast genome. Similar numbers of genes were reported to be regulated in the closely related, but pathogenic, yeast $C$. glabrata following exposure to glucose starvation, osmotic, oxidative and heat stresses (72). Furthermore, in the divergent yeast, $S z$. pombe approximately 140 genes are commonly upregulated and 100 downregulated in response to a range of stresses including osmotic, oxidative, heavy metal, DNA damage, and heat stress (69). Common processes were represented in the induced core stress gene sets such as carbohydrate metabolism, protein folding and degradation, redox regulation and DNA repair. In contrast, repressed genes were associated with energy consuming and growth-related processes, including RNA processing, transcription and translation, and biosynthesis of ribosomes and nucleotides. Interestingly, the pathogenic fungus $C$. albicans mounts a significantly smaller CSR than those described above, as only 24 and 37 genes were commonly induced or repressed, respectively, by osmotic, oxidative and heavy metal stress (71). Despite this, the CSR genes in $C$. albicans do belong to some of the same functional categories as those in $S$. cerevisiae, $S z$. pombe, and $C$. glabrata, suggesting that some of the processes involved in the CSR are evolutionarily conserved.

In $S$. cerevisiae, different signalling pathways and transcription factors converge to control a common set of stress genes, although the functionally redundant Msn2 and Msn4 $\left(\mathrm{C}_{2} \mathrm{H}_{2}\right)_{2}$ zinc finger transcription factors play a major role $(20,68)$. Consistent with this, many of the CSR genes carry a stress response element (STRE) within their promoters, to which Msn2 and Msn4 bind $(20,68)$. This Msn2/4-mediated CSR forms the basis of the previously characterised General Stress Response in $S$. cerevisiae, which is comprised of a Msn2/4STRE regulon that is activated in response to diverse stresses (196). Msn2/4 rapidly accumulate in the nucleus following a range of nutrient and stress conditions $(197,198)$, and are subject to complex regulation by a number of pathways (199). However, a number of other factors also regulate the CSR in S. cerevisiae. In response to osmotic stress the Hog 1 SAPK contributes to the regulation of CSR genes (20), likely through the Hot1 transcription factor (60), whereas the Yap1 AP-1-like transcription factor contributes to CSR gene induction post-oxidative stress (20). In addition, the Mec1 DNA-damage specific pathway contributes to CSR gene regulation in response to DNA damaging agents (200).

Recently, it has been shown that the Msn2 transcription factor also makes a major contribution to the regulation of CSR genes in C. glabrata (72). Consistent with this, in this pathogenic yeast, Msn2 rapidly localizes to the nucleus following glucose starvation and in response to osmotic, oxidative or heat stress (72). In stark contrast, homologues of Msn2 and Msn4 do not have the same broad stress-protective roles in C. albicans $(194,201)$, which may in fact contribute to the relatively small CSR seen in this fungus (71). Moreover, in $S z$. pombe, which lacks close homologues of Msn2/4, the CSR is regulated by a different mechanism. In this yeast, the Sty1 SAPK is activated in response to diverse stress conditions including osmotic, oxidative and heat stress, nutrient limitation, UV light and cold stress (202). Following activation, Sty 1 accumulates in the nucleus where it phosphorylates the 
Atf1 transcription factor leading to its activation and stabilisation (96-98). Sty1, and to a lesser extent, Atf1 are the major regulators of the CSR in Sz. pombe (69). It is interesting that CSR genes implicated in stress defense are dependent on Sty1 and Atf1, whereas CSR genes with regulatory functions are induced by Sty1 independently of Atf1 (69).

Similar to the Sty1 SAPK in Sz. pombe, the Hog1 SAPK in the fungal pathogen C. albicans is activated in response to diverse stresses (111). Significantly, a CSR was only observed after treating cells with three stress conditions - osmotic, oxidative and heavy metal stress that activate $\operatorname{Hog} 1(70,71)$. Intriguingly, however, Hog1 regulated the transcriptional responses to osmotic and heavy metal stresses, but not to oxidative stress, and this was reflected in the role of $\mathrm{Hog} 1$ in the regulation of $C$. albicans CSR genes. Instead, the Cap1 AP-1-like transcription factor regulated the $C$. albicans CSR following oxidative stress (71). Thus, the $C$. albicans SAPK pathway functions in parallel with other pathways to regulate the core transcriptional response to stress. Hence, although aspects of a CSR are conserved across the fungal kingdom, the mechanisms underlying its regulation have diverged significantly.

What is the physiological role of a CSR? Earlier studies in $S$. cerevisiae revealed a phenomenon called 'stress cross protection', in which exposure to a non-lethal dose of one stress provided significant protection to the subsequent exposure of a potentially lethal dose of a second unrelated stress (203) (Figure 2). Such stress cross protection was impaired in the presence of cycloheximide illustrating a role for new protein synthesis (203). The Msn2/4 mediated general stress response in $S$. cerevisiae, together with the identification of the CSR, probably accounts for the observed stress-cross protection in a number of fungi $(69,72,111)$. Interestingly, subsequent studies have revealed that the CSR triggered by the initial low stress dose, is not required to survive this stress, but instead provides protection against the second stress (204). Furthermore, the actual genes and processes necessary to acquire resistance to the same severe stress are different depending on the nature of the initial mild stressor. In other words, the mechanism of stress-cross protection is determined by the initial stress (205). This probably underlies previous findings that stress-cross protection is context dependent and not always reciprocal (204) (Figure 2).

But why might stress-cross protection have evolved? Some microbes occupy reasonably predictable niches in which one environmental input is generally followed by a second input. In such cases, fungi that have evolved to anticipate the second input following exposure to the first would have a fitness advantage (206) Domesticated brewing yeasts provide an excellent example of this "adaptive prediction" because, as they ferment sugars, they become exposed to increasing ethanol concentrations (input 1) and then, when the sugars are exhausted, they switch to respiratory metabolism and become exposed to oxidative stress (input 2). Presumably as a consequence of this environmental predictability, S. cerevisiae has evolved to activate oxidative stress genes following exposure to ethanol (207). Asymmetric adaptive prediction appears to have evolved in other fungi such as $C$. albicans $(208,209)$. Unlike $S$. cerevisiae, this pathogen displays increased resistance to acute oxidative stress following exposure to glucose (210), which possibly reflects anticipation of phagocytic attack after entry to the bloodstream. Therefore, it is conceivable that CSRs have evolved as a result of adaptive prediction. 


\section{ADAPTING TO STRESS IN NATURAL ENVIRONMENTS}

\section{Combinatorial Stress Responses}

Our understanding of stress responses in yeast has been shaped largely by the study of individual stresses, or as discussed in the previous section, how the prior exposure to one stress can provide stress cross protection to a second unrelated stress. However, the diverse environments that fungi occupy are complex and dynamic, and it is conceivable that fungi will often be exposed to multiple stresses. At times these stresses may be imposed sequentially, in which stress cross protection may facilitate survival. However, at other times, a fungus may be exposed simultaneously to multiple stresses, termed 'combinatorial stress'. Recent studies have revealed that certain combinations of stresses are particularly potent in terms of their ability to kill functionally divergent model (S. cerevisiae, Sz. pombe) and pathogenic (C. albicans, $C$. glabrata) yeasts $(211,212)$. Notably, all of these species are acutely sensitive to combinations of cationic and oxidative stresses (211). Pathogenic fungi encounter this combination of stresses following phagocytosis; microbes are exposed to high levels of ROS generated by the respiratory burst (213), and the resulting accumulation of anionic charge is compensated by a rush of potassium $\left(\mathrm{K}^{+}\right)$ions into the endocytic vacuole which simultaneously imposes a cationic stress (213). Strikingly, studies investigating the mechanistic basis underlying the exquisite sensitivity of $C$. albicans to such combinations of stress have revealed that exposure to cationic stress prevents this pathogen from mounting an oxidative stress response. The oxidative stress regulon in $C$. albicans is largely regulated by the Cap1 AP-1-like transcription factor (214), and Cap1 fails to be activated following exposure to combinatorial oxidative and cationic stress $(211,215)$. This phenomenon, which has been termed "stress pathway interference" (211) (Figure 3), contrasts starkly with that of stress cross-protection in which exposure to one stress protects against the subsequent exposure to a different stress (104). Exposure of $C$. albicans to $\mathrm{H}_{2} \mathrm{O}_{2}$ triggers the rapid oxidation of Cap1, this masks the nuclear export sequence, resulting in the rapid nuclear accumulation of Cap1 and the induction of Cap1-dependent genes. However, cationic stress inhibits this Cap1-mediated oxidative stress response in two ways. First, cations inhibit catalase activity which triggers significant increases in intracellular ROS levels following combinations of cationic and oxidative stresses (211). Such high levels of ROS trap Cap1 in a partially oxidised form that fails to induce target antioxidant-encoding genes (215). Second, cations stimulate the interaction of Cap1 with the nuclear export factor Crm1, which results in significant delays in the $\mathrm{H}_{2} \mathrm{O}_{2}$-induced nuclear accumulation of this transcription factor. Importantly, the cationic stress-mediated inhibition of oxidative stress responses contributes to the fungicidal potency of human neutrophils, as effective killing of $C$. albicans is dependent on the combinatorial effects of the oxidative burst and cationic fluxes (211). These findings may also explain the lack of expression of $C$. albicans oxidative stress genes in certain host niches, such as during systemic infections of the kidney, despite the presence of neutrophil infiltrates (216).

Although to date studies have focused on combinatorial oxidative plus cationic stress, it is feasible that other stress combinations will influence stress outputs (208). Indeed, we have found that $\mathrm{pH}$ has drastic effects on the oxidative stress tolerance of a number of fungi (JQ, AJPB unpublished). This is an exciting new area in the field of stress responses that is likely 
to be of broad relevance across the fungal kingdom due to the complexity of natural environments.

\section{Dynamics of Stress Responses}

Our perspectives of fungal stress responses and stress resistance have been shaped largely by our experimental approaches. For example, plate assays, which are widely used to examine stress resistance, often do not differentiate between the ability of a strain to survive immediately following exposure to an acute stress and its ability to adapt and resume growth in the longer term. Also, the availability of powerful molecular genetics and genomics approaches has led to major advances in our understanding of fungal stress responses at the gene and protein levels, but the metabolic changes that that underlie stress adaptation have received less attention. Yet these changes play vital roles in fungal stress resistance.

The resistance of yeast cells to stress is enhanced by increases in metabolic flux towards the generation of antioxidants such as glutathione and of stress protectants such as trehalose (123, 217-220). Like the accumulation of glycerol in response to hyper-osmotic stress (36), these increases in glutathione and trehalose levels are mediated in large part by changes in gene expression and enzyme synthesis, and hence are slow. Other metabolic responses are much faster. For example, there is a rapid shift in metabolic flux from lower glycolysis towards the pentose phosphate pathway upon exposure to oxidative stress (73). This metabolic shift, which is mediated through the sensitivity of glyceraldehyde-3-phosphate dehydrogenase (GAPDH) to oxidative inactivation (221), increases the NADPH synthesis, and hence the availability of protective reducing equivalents (73). This metabolic response to oxidative stress occurs within seconds, preceding transcriptional responses to oxidative stress (222).

Clearly, different aspects of a fungal adaptive response take place over different timescales (36) (Figure 4). Initial metabolic and biophysical responses can occur within seconds to minutes $(37,222)$. Signal transduction is activated rapidly, within minutes, and often remains active for tens of minutes (36). This triggers changes in gene expression: transcript levels often rise within five minutes and, depending on the stability of the mRNA, can remain elevated for tens of minutes. Resultant changes in enzyme levels are often observed in tens of minutes and can last for hours, depending on the stability of these proteins. Consequently, the accumulation metabolites such as glycerol can take tens of minutes to an hour.

While these general principles hold, the dynamics of a stress response are strongly influenced by the dose. Large single doses are often applied to experimentally dissect a stress response in vitro. However, in reality that stress response might have evolved to maintain cellular homeostasis in the face of less acute but multiple challenges. For example, researchers often use large acute heat shocks to study thermal adaptation, although many fungi encounter less dramatic thermal fluctuations in the wild. Also, researchers generally examine the impact of a single dose, and yet fungi can face repetitive doses of certain stresses in some habitats (e.g. repetitive hypo-osmotic shock during rainfall). The mathematical modelling of stress responses permits the analysis of the vast theoretical space represented by variations in the dose, exposure time and frequency of a stress. Indeed, 
mathematical modelling is already improving our appreciation of the dynamics of stress responses, the influence of stress dose, and their impact on stress adaptation in fungi $(36,63$, $223,224)$. These dynamics are significant because they influence the length of time for which the molecular memory of a stress is retained, and hence the period over which stress adaptation provides protection against a subsequent stress (225) (see Core Stress Response).

\section{Impact of Growth Conditions upon Stress Resistance}

Historically, the dissection of fungal stress responses has largely been performed under a relatively small set of experimental conditions to facilitate comparison between studies. This has influenced our perceptions of stress adaptation. For example, it is well known that changes in carbon source exert dramatic effects upon stress resistance in $S$. cerevisiae. Yet stress adaptation in $C$. albicans has largely been examined using glucose-rich media although this fungus generally inhabits glucose-poor niches. Also temperature affects stress responses (29).

A shift from glucose to non-fermentative carbon source increases stress resistance in $S$. cerevisiae, partly through activation of the CSR. Glucose inhibits the CSR through Msn2/ Msn4 phosphorylation, which is mediated by Ras-cAMP-protein kinase A signalling (226). Phosphorylation of Msn2/Msn4 prevents the nuclear accumulation of these transcription factors, thereby blocking their activation of core stress genes (197). Glucose also regulates $Y A P 1$ (the AP1-like transcription factor central to the transcriptional response to oxidative stress) and ENA1 (a P-type ATPase $\mathrm{Na}^{+}$pump required for cationic stress resistance) (227, 228).

Changes in carbon source also affect stress resistance in $C$. albicans. Exposure to glucose increases oxidative stress resistance by upregulating oxidative stress genes in this yeast (210). In contrast, growth on glucose decreases the resistance of $C$. albicans to osmotic and cell wall stresses, in large part through carbon source-dependent changes in the pre-adapted state of the cell wall $(37,229)$. Consequently, as different host niches contain different carbon sources, the nature of a niche must determine the ability of $C$. albicans to counteract stresses in that niche. Not surprisingly, the virulence of this pathogen is influenced by the carbon source (229).

\section{CONCLUSIONS AND PERSPECTIVES}

It is clear that major advances have been made in our understanding of fungal stress adaptation over the last decades. However, much remains to be learned with regard to how cells respond to stress in their natural environments. Several issues should be addressed.

First, many gaps remain in our understanding of stress signaling pathways and of stress responses themselves, even for individual stresses in model fungi. Just one example is our understanding of how nitrosative stress responses are regulated, which is rudimentary compared to oxidative and osmotic stress signaling even in $S$. cerevisiae. The situation is worse for model ascomycete and basidiomycete pathogens such as $C$. albicans and $C r$. neoformans. Their life-styles differ markedly from $S$. cerevisiae and $S z$. pombe, and differential evolutionary pressures appear to have driven regulatory rewiring and niche- 
specific tuning of stress responses, yielding different stress sensitivities and different patterns of stress cross-protection.

Second, our understanding of the dynamics of stress adaptation needs to improve, incorporating the immediate and long term contributions of metabolic responses and biophysical changes alongside those driven by transcriptional and post-translational gene regulation. This needs to be considered alongside the issue of population heterogeneity. The molecular basis for the differential stress sensitivity of genetically identical cells experiencing the same environmental conditions needs to be better understood. To achieve this we require experimental approaches that provide dynamic views of cell-to-cell variation at high resolution.

Third, more consideration needs to be given to the nature of the stresses that are encountered by a fungus in its natural habitat, and the nature of the microenvironment(s) in which it must respond to these stresses. How acute is the stress, how long is the exposure, and how frequently is it encountered? This is significant because, in reality, some fungal stress responses may have evolved to maintain cellular homeostasis in the face of modest but repetitive challenges rather than single acute doses (see Dynamics of Stress Responses). Is the stress imposed in combination with other environmental insults? This should be considered because certain combinations of stress can yield unexpected stress responses (see Combinatorial Stress Responses). What is the temperature of the niche and what nutrients are available? These factors are important because they strongly influence the pre-adapted state of the fungus and hence its ability to counteract the stress (see Impact of Growth Conditions upon Stress Resistance).

If these issues are addressed, there will be a paradigm shift in our understanding of fungal stress responses and their relevance to survival in natural environments.

\title{
Acknowledgments
}

\begin{abstract}
We thank our numerous friends and colleagues for stimulating discussions about stress adaptation. We are also grateful to the following bodies for generously supporting our research. A.J.P.B was funded by the European Research Council (STRIFE, ERC-2009-AdG-249793), the UK Medical Research Council (MR/M026663/1), the UK Biotechnology and Biological Research Council (BB/K017365/1) and the Wellcome Trust (080088; 097377). L.E.C. is supported by the Canadian Institutes of Health Research Operating Grants (MOP-86452 and MOP-119520), the Natural Sciences and Engineering Research Council (NSERC) of Canada Discovery Grants (06261 and 462167), an NSERC E.W.R. Steacie Memorial Fellowship (477598), and a Canada Research Chair in Microbial Genomics and Infectious Disease. Work in the A.D.P. laboratory is funded by grants from the Spanish Ministerio de Innovación y Competitividad (MINECO; BIO2013-47870-R), the European Commission (Marie Curie ITN FUNGIBRAIN; FP7-PEOPLE-ITN-607963) and the Junta de Andalucia (BIO296). J.Q. is funded by the UK Biotechnology and Biological Research Council (BB/K016939/1) and the Wellcome Trust (097377).
\end{abstract}

\section{References}

1. Hawksworth DL. Global species numbers of fungi: are tropical studies and molecular approaches contributing to a more robust estimate? Biodivers Conserv. 2012; 21:2425-2433.

2. Fisher MC, Henk DA, Briggs CJ, Brownstein JS, Madoff LC, McCraw SL, Gurr SJ. Emerging fungal threats to animal, plant and ecosystem health. Nature. 2012; 484:186-194. [PubMed: 22498624]

3. de Hoog, GS., Guarro, J., Gene, J., Figueras, MJ. Atlas of Clinical Fungi. 2. Centraalbureau voor Schimmelcultures, Utrecht; The Netherlands/Universitat Rovira i Virgili, Reus, Spain: 2000. 
4. Lindquist S, Craig EA. The heat-shock proteins. Annu Rev Genet. 1988; 22:631-677. [PubMed: 2853609]

5. Steen BR, Lian T, Zuyderduyn S, MacDonald WK, Marra M, Jones SJ, Kronstad JW. Temperatureregulated transcription in the pathogenic fungus Cryptococcus neoformans. Genome Res. 2002; 12:1386-1400. [PubMed: 12213776]

6. Brown SM, Campbell LT, Lodge JK. Cryptococcus neoformans, a fungus under stress. Curr Opin Microbiol. 2007; 10:320-325. [PubMed: 17707685]

7. Pocsi I, Miskei M, Karanyi Z, Emri T, Ayoubi P, Pusztahelyi T, Balla G, Prade RA. Comparison of gene expression signatures of diamide, $\mathrm{H} 2 \mathrm{O} 2$ and menadione exposed Aspergillus nidulans cultures--linking genome-wide transcriptional changes to cellular physiology. BMC Genomics. 2005; 6:182. [PubMed: 16368011]

8. Breuer U, Harms H. Debaryomyces hansenii--an extremophilic yeast with biotechnological potential. Yeast. 2006; 23:415-437. [PubMed: 16652409]

9. Stefanini I, Dapporto L, Legras JL, Calabretta A, Di Paola M, De Filippo C, Viola R, Capretti P, Polsinelli M, Turillazzi S, Cavalieri D. Role of social wasps in Saccharomyces cerevisiae ecology and evolution. Proc Natl Acad Sci U S A. 2012; 109:13398-13403. [PubMed: 22847440]

10. Roetzer A, Gratz N, Kovarik P, Schuller C. Autophagy supports Candida glabrata survival during phagocytosis. Cell Microbiol. 2010; 12:199-216. [PubMed: 19811500]

11. Nikolaou E, Agrafioti I, Stumpf M, Quinn J, Stansfield I, Brown AJ. Phylogenetic diversity of stress signalling pathways in fungi. BMC Evol Biol. 2009; 9:44. [PubMed: 19232129]

12. Shapiro RS, Cowen LE. Thermal control of microbial development and virulence: molecular mechanisms of microbial temperature sensing. MBio. 2012; 3 00238-00212.

13. Bergman A, Casadevall A. Mammalian endothermy optimally restricts fungi and metabolic costs. MBio. 2010; 1 00212-00210.

14. Garcia-Solache MA, Casadevall A. Global warming will bring new fungal diseases for mammals. MBio. 2010; 1 00061-00010.

15. Klein BS, Tebbets B. Dimorphism and virulence in fungi. Curr Opin Microbiol. 2007; 10:314-319. [PubMed: 17719267]

16. Gow NA, van de Veerdonk FL, Brown AJ, Netea MG. Candida albicans morphogenesis and host defence: discriminating invasion from colonization. Nat Rev Microbiol. 2012; 10:112-122.

17. Shapiro RS, Robbins N, Cowen LE. Regulatory circuitry governing fungal development, drug resistance, and disease. Microbiol Mol Biol Rev. 2011; 75:213-267. [PubMed: 21646428]

18. Leach MD, Farrer RA, Tan K, Miao Z, Walker LA, Cuomo CA, Wheeler RT, Brown AJ, Wong KH, Cowen LE. Hsf1 and Hsp90 orchestrate temperature-dependent global transcriptional remodelling and chromatin architecture in Candida albicans. Nat Commun. 2016; 7:11704. [PubMed: 27226156]

19. Leach MD, Klipp E, Cowen LE, Brown AJ. Fungal Hsp90: a biological transistor that tunes cellular outputs to thermal inputs. Nat Rev Microbiol. 2012; 10:693-704. [PubMed: 22976491]

20. Gasch AP, Spellman PT, Kao CM, Carmel_Harel O, Eisen MB, Storz G, Botstein D, Brown PO. Genomic expression programs in the response of yeast cells to environmental changes. Molecular Biology of the Cell. 2000; 11:4241-4257. [PubMed: 11102521]

21. Nicholls S, Leach MD, Priest CL, Brown AJ. Role of the heat shock transcription factor, Hsf1, in a major fungal pathogen that is obligately associated with warm-blooded animals. Mol Microbiol. 2009; 74:844-861. [PubMed: 19818013]

22. Campos EI, Fillingham J, Li G, Zheng H, Voigt P, Kuo WH, Seepany H, Gao Z, Day LA, Greenblatt JF, Reinberg D. The program for processing newly synthesized histones H3.1 and H4. Nat Struct Mol Biol. 2010; 17:1343-1351. [PubMed: 20953179]

23. Sawarkar R, Sievers C, Paro R. Hsp90 globally targets paused RNA polymerase to regulate gene expression in response to environmental stimuli. Cell. 2012; 149:807-818. [PubMed: 22579285]

24. Zhao R, Davey M, Hsu YC, Kaplanek P, Tong A, Parsons AB, Krogan N, Cagney G, Mai D, Greenblatt J, Boone C, Emili A, Houry WA. Navigating the chaperone network: an integrative map of physical and genetic interactions mediated by the hsp90 chaperone. Cell. 2005; 120:715-727. [PubMed: 15766533] 
25. Taipale M, Jarosz DF, Lindquist S. HSP90 at the hub of protein homeostasis: emerging mechanistic insights. Nat Rev Mol Cell Biol. 2010; 11:515-528. [PubMed: 20531426]

26. Taipale M, Tucker G, Peng J, Krykbaeva I, Lin ZY, Larsen B, Choi H, Berger B, Gingras AC, Lindquist $\mathrm{S}$. A quantitative chaperone interaction network reveals the architecture of cellular protein homeostasis pathways. Cell. 2014; 158:434-448. [PubMed: 25036637]

27. Diezmann S, Michaut M, Shapiro RS, Bader GD, Cowen LE. Mapping the Hsp90 genetic interaction network in Candida albicans reveals environmental contingency and rewired circuitry. PLoS Genet. 2012; 8:e1002562. [PubMed: 22438817]

28. Hawle P, Horst D, Bebelman JP, Yang XX, Siderius M, van der Vies SM. Cdc37p is required for stress-induced high-osmolarity glycerol and protein kinase $\mathrm{C}$ mitogen-activated protein kinase pathway functionality by interaction with Hog1p and Slt2p (Mpk1p). Eukaryot Cell. 2007; 6:521532. [PubMed: 17220467]

29. Leach MD, Budge S, Walker L, Munro C, Cowen LE, Brown AJ. Hsp90 orchestrates transcriptional regulation by Hsf1 and cell wall remodelling by MAPK signalling during thermal adaptation in a pathogenic yeast. PLoS Pathog. 2012; 8:e1003069. [PubMed: 23300438]

30. O'Meara TR, Veri AO, Polvi EJ, Li X, Valaei SF, Diezmann S, Cowen LE. Mapping the Hsp90 Genetic Network Reveals Ergosterol Biosynthesis and Phosphatidylinositol-4-Kinase Signaling as Core Circuitry Governing Cellular Stress. PLoS Genet. 2016; 12:e1006142. [PubMed: 27341673]

31. Hohmann S. Osmotic stress signaling and osmoadaptation in yeasts. Microbiol Mol Biol Rev. 2002; 66:300-372. [PubMed: 12040128]

32. Ferreira C, van Voorst F, Martins A, Neves L, Oliveira R, Kielland-Brandt MC, Lucas C, Brandt A. A member of the sugar transporter family, Stl1p is the glycerol/H+ symporter in Saccharomyces cerevisiae. Mol Biol Cell. 2005; 16:2068-2076. [PubMed: 15703210]

33. Duskova M, Ferreira C, Lucas C, Sychrova H. Two glycerol uptake systems contribute to the high osmotolerance of Zygosaccharomyces rouxii. Mol Microbiol. 2015; 97:541-559. [PubMed: 25943012]

34. Kayingo G, Martins A, Andrie R, Neves L, Lucas C, Wong B. A permease encoded by STL1 is required for active glycerol uptake by Candida albicans. Microbiology. 2009; 155:1547-1557. [PubMed: 19383674]

35. Luyten K, Albertyn J, Skibbe WF, Prior BA, Ramos J, Thevelein JM, Hohmann S. Fps1, a yeast member of the MIP family of channel proteins, is a facilitator for glycerol uptake and efflux and is inactive under osmotic stress. Embo J. 1995; 14:1360-1371. [PubMed: 7729414]

36. Klipp E, Nordlander B, Kruger R, Gennemark P, Hohmann S. Integrative model of the response of yeast to osmotic shock. Nat Biotechnol. 2005; 23:975-982. [PubMed: 16025103]

37. Ene IV, Walker LA, Schiavone M, Lee KK, Martin-Yken H, Dague E, Gow NA, Munro CA, Brown AJ. Cell Wall Remodeling Enzymes Modulate Fungal Cell Wall Elasticity and Osmotic Stress Resistance. MBio. 2015; 6:e00986. [PubMed: 26220968]

38. Muir A, Roelants FM, Timmons G, Leskoske KL, Thorner J. Down-regulation of TORC2-Ypk1 signaling promotes MAPK-independent survival under hyperosmotic stress. Elife. 2015; 4:09336.

39. Hohmann S, Krantz M, Nordlander B. Yeast osmoregulation. Methods Enzymol. 2007; 428:29-45. [PubMed: 17875410]

40. Yu Z, Armant O, Fischer R. Fungi use the SakA (HogA) pathway for phytochrome-dependent light signalling. Nat Microbiol. 2016; 1:16019. [PubMed: 27572639]

41. Posas F, Wurgler-Murphy SM, Maeda T, Witten EA, Thai TC, Saito H. Yeast HOG1 MAP kinase cascade is regulated by a multistep phosphorelay mechanism in the SLN1-YPD1-SSK1 "twocomponent" osmosensor. Cell. 1996; 86:865-875. [PubMed: 8808622]

42. Posas F, Saito H. Activation of the yeast SSK2 MAP kinase kinase kinase by the SSK1 twocomponent response regulator. Embo J. 1998; 17:1385-1394. [PubMed: 9482735]

43. Tatebayashi K, Yamamoto K, Tanaka K, Tomida T, Maruoka T, Kasukawa E, Saito H. Adaptor functions of Cdc42, Ste50, and Sho1 in the yeast osmoregulatory HOG MAPK pathway. Embo J. 2006; 25:3033-3044. [PubMed: 16778768]

44. Wu C, Jansen G, Zhang J, Thomas DY, Whiteway M. Adaptor protein Ste50p links the Ste11p MEKK to the HOG pathway through plasma membrane association. Genes Dev. 2006; 20:734746. [PubMed: 16543225] 
45. Maeda T, Takekawa M, Saito H. Activation of yeast PBS2 MAPKK by MAPKKKs or by binding of an SH3-containing osmosensor. Science. 1995; 269:554-558. [PubMed: 7624781]

46. Tatebayashi K, Tanaka K, Yang HY, Yamamoto K, Matsushita Y, Tomida T, Imai M, Saito H. Transmembrane mucins Hkr1 and Msb2 are putative osmosensors in the SHO1 branch of yeast HOG pathway. Embo J. 2007; 26:3521-3533. [PubMed: 17627274]

47. Tanaka K, Tatebayashi K, Nishimura A, Yamamoto K, Yang HY, Saito H. Yeast osmosensors Hkr1 and Msb2 activate the Hog1 MAPK cascade by different mechanisms. Sci Signal. 2014; 7:ra21. [PubMed: 24570489]

48. Yamamoto K, Tatebayashi K, Saito H. Binding of the Extracellular Eight-Cysteine Motif of Opy2 to the Putative Osmosensor Msb2 Is Essential for Activation of the Yeast High-Osmolarity Glycerol Pathway. Mol Cell Biol. 2016; 36:475-487.

49. Pitoniak A, Birkaya B, Dionne HM, Vadaie N, Cullen PJ. The Signaling Mucins Msb2 and Hkr1 Differentially Regulate the Filamentation Mitogen-activated Protein Kinase Pathway and Contribute to a Multimodal Response. Mol Biol Cell. 2009; 20:3101-3114. [PubMed: 19439450]

50. Nishimura A, Yamamoto K, Oyama M, Kozuka-Hata H, Saito H, Tatebayashi K. Scaffold Protein Ahk1, Which Associates with Hkr1, Sho1, Ste11, and Pbs2, Inhibits Cross Talk Signaling from the Hkr1 Osmosensor to the Kss1 Mitogen-Activated Protein Kinase. Mol Cell Biol. 2016; 36:11091123. [PubMed: 26787842]

51. Nikolaou E, Agrafioti I, Stumpf M, Quinn J, Stansfield I, Brown AJP. Phylogenetic diversity of stress signalling pathways in fungi. BMC Evolutionary Biology. 2009; 9:44. [PubMed: 19232129]

52. Buck V, Quinn J, Soto Pino T, Martin H, Saldanha J, Makino K, Morgan BA, Millar JB. Peroxide sensors for the fission yeast stress-activated mitogen-activated protein kinase pathway. Mol Biol Cell. 2001; 12:407-419. [PubMed: 11179424]

53. Roman E, Cottier F, Ernst JF, Pla J. Msb2 signaling mucin controls activation of Cek1 mitogenactivated protein kinase in Candida albicans. Eukaryot Cell. 2009; 8:1235-1249. [PubMed: 19542310]

54. Roman E, Nombela C, Pla J. The Sho1 adaptor protein links oxidative stress to morphogenesis and cell wall biosynthesis in the fungal pathogen Candida albicans. Mol Cell Biol. 2005; 25:1061110627. [PubMed: 16287872]

55. Cheetham J, Smith DA, da Silva Dantas A, Doris KS, Patterson MJ, Bruce CR, Quinn J. A single MAPKKK regulates the Hog1 MAPK pathway in the pathogenic fungus Candida albicans. Mol Biol Cell. 2007; 18:4603-4614. [PubMed: 17804815]

56. Chauhan N, Inglis D, Roman E, Pla J, Li D, Calera JA, Calderone R. Candida albicans response regulator gene SSK1 regulates a subset of genes whose functions are associated with cell wall biosynthesis and adaptation to oxidative stress. Eukaryot Cell. 2003; 2:1018-1024. [PubMed: 14555484]

57. Gregori C, Schuller C, Roetzer A, Schwarzmuller T, Ammerer G, Kuchler K. The high-osmolarity glycerol response pathway in the human fungal pathogen Candida glabrata strain ATCC 2001 lacks a signaling branch that operates in baker's yeast. Eukaryot Cell. 2007; 6:1635-1645. [PubMed: 17616630]

58. Bahn YS, Geunes-Boyer S, Heitman J. Ssk2 mitogen-activated protein kinase kinase kinase governs divergent patterns of the stress-activated Hog1 signaling pathway in Cryptococcus neoformans. Eukaryot Cell. 2007; 6:2278-2289. [PubMed: 17951522]

59. Bahn YS, Kojima K, Cox GM, Heitman J. Specialization of the HOG pathway and its impact on differentiation and virulence of Cryptococcus neoformans. Mol Biol Cell. 2005; 16:2285-2300. [PubMed: 15728721]

60. Rep M, Krantz M, Thevelein JM, Hohmann S. The transcriptional response of Saccharomyces cerevisiae to osmotic shock. Hot1p and Msn2p/Msn4p are required for the induction of subsets of high osmolarity glycerol pathway-dependent genes. J Biol Chem. 2000; 275:8290-8300. [PubMed: 10722658]

61. Lee J, Reiter W, Dohnal I, Gregori C, Beese-Sims S, Kuchler K, Ammerer G, Levin DE. MAPK Hog1 closes the $S$. cerevisiae glycerol channel Fps1 by phosphorylating and displacing its positive regulators. Genes Dev. 2013; 27:2590-2601. [PubMed: 24298058] 
62. Yaakov G, Duch A, Garcia-Rubio M, Clotet J, Jimenez J, Aguilera A, Posas F. The stress-activated protein kinase Hog1 mediates S phase delay in response to osmostress. Mol Biol Cell. 2009; 20:3572-3582. [PubMed: 19477922]

63. Muzzey D, Gomez-Uribe CA, Mettetal JT, van Oudenaarden A. A systems-level analysis of perfect adaptation in yeast osmoregulation. Cell. 2009; 138:160-171. [PubMed: 19596242]

64. Halliwell B. Reactive species and antioxidants. Redox biology is a fundamental theme of aerobic life. Plant Physiol. 2006; 141:312-322. [PubMed: 16760481]

65. Cadenas E, Davies KJ. Mitochondrial free radical generation, oxidative stress, and aging. Free Radic Biol Med. 2000; 29:222-230. [PubMed: 11035250]

66. O'Brien JA, Daudi A, Butt VS, Bolwell GP. Reactive oxygen species and their role in plant defence and cell wall metabolism. Planta. 2012; 236:765-779. [PubMed: 22767200]

67. Brown AJ, Haynes K, Quinn J. Nitrosative and oxidative stress responses in fungal pathogenicity. Curr Opin Microbiol. 2009; 12:384-391. [PubMed: 19616469]

68. Causton HC, Ren B, Koh SS, Harbison CT, Kanin E, Jennings EG, Lee TI, True HL, Lander ES, Young RA. Remodeling of yeast genome expression in response to environmental changes. Molecular Biology of the Cell. 2001; 12:323-337. [PubMed: 11179418]

69. Chen D, Toone WM, Mata J, Lyne R, Burns G, Kivinen K, Brazma A, Jones N, Bahler J. Global transcriptional responses of fission yeast to environmental stress. Molecular Biology of the Cell. 2003; 14:214-229. [PubMed: 12529438]

70. Enjalbert B, Nantel A, Whiteway M. Stress-induced Gene Expression in Candida albicans: Absence of a General Stress Response. Molecular Biology of the Cell. 2003; 14:1460-1467. [PubMed: 12686601]

71. Enjalbert B, Smith DA, Cornell MJ, Alam I, Nicholls S, Brown AJ, Quinn J. Role of the Hog1 stress-activated protein kinase in the global transcriptional response to stress in the fungal pathogen Candida albicans. Mol Biol Cell. 2006; 17:1018-1032. [PubMed: 16339080]

72. Roetzer A, Gregori C, Jennings AM, Quintin J, Ferrandon D, Butler G, Kuchler K, Ammerer G, Schuller C. Candida glabrata environmental stress response involves Saccharomyces cerevisiae Msn2/4 orthologous transcription factors. Molecular Microbiology. 2008; 69:603-620. [PubMed: 18547390]

73. Ralser M, Wamelink MM, Kowald A, Gerisch B, Heeren G, Struys EA, Klipp E, Jakobs C, Breitenbach M, Lehrach H, Krobitsch S. Dynamic rerouting of the carbohydrate flux is key to counteracting oxidative stress. J Biol. 2007; 6:10. [PubMed: 18154684]

74. Flattery-O'Brien JA, Dawes IW. Hydrogen peroxide causes RAD9-dependent cell cycle arrest in G2 in Saccharomyces cerevisiae whereas menadione causes G1 arrest independent of RAD9 function. J Biol Chem. 1998; 273:8564-8571. [PubMed: 9535829]

75. Finn K, Lowndes NF, Grenon M. Eukaryotic DNA damage checkpoint activation in response to double-strand breaks. Cell Mol Life Sci. 2012; 69:1447-1473. [PubMed: 22083606]

76. da Silva Dantas A, Patterson MJ, Smith DA, Maccallum DM, Erwig LP, Morgan BA, Quinn J. Thioredoxin regulates multiple hydrogen peroxide-induced signaling pathways in Candida albicans. Mol Cell Biol. 2010; 30:4550-4563. [PubMed: 20679492]

77. Shi QM, Wang YM, Zheng XD, Lee RT, Wang Y. Critical role of DNA checkpoints in mediating genotoxic-stress-induced filamentous growth in Candida albicans. Mol Biol Cell. 2007; 18:815826. [PubMed: 17182857]

78. Delaunay A, Isnard AD, Toledano MB. $\mathrm{H}_{2} \mathrm{O}_{2}$ sensing through oxidation of the Yap1 transcription factor. Embo J. 2000; 19:5157-5166. [PubMed: 11013218]

79. Delaunay A, Pflieger D, Barrault MB, Vinh J, Toledano MB. A thiol peroxidase is an $\mathrm{H}_{2} \mathrm{O}_{2}$ receptor and redox-transducer in gene activation. Cell. 2002; 111:471-481. [PubMed: 12437921]

80. Veal EA, Ross SJ, Malakasi P, Peacock E, Morgan BA. Ybp1 is required for the hydrogen peroxide-induced oxidation of the Yap1 transcription factor. J Biol Chem. 2003; 278:3089630904. [PubMed: 12743123]

81. Wood MJ, Storz G, Tjandra N. Structural basis for redox regulation of Yap1 transcription factor localization. Nature. 2004; 430:917-921. [PubMed: 15318225]

82. Patterson MJ, McKenzie CG, Smith DA, da Silva Dantas A, Sherston S, Veal EA, Morgan BA, MacCallum DM, Erwig LP, Quinn J. Ybp1 and Gpx3 signaling in Candida albicans govern 
hydrogen peroxide-induced oxidation of the Cap1 transcription factor and macrophage escape. Antioxid Redox Signal. 2013; 19:2244-2260. [PubMed: 23706023]

83. Bozonet SM, Findlay VJ, Day AM, Cameron J, Veal EA, Morgan BA. Oxidation of a eukaryotic 2Cys peroxiredoxin is a molecular switch controlling the transcriptional response to increasing levels of hydrogen peroxide. J Biol Chem. 2005; 280:23319-23327. [PubMed: 15824112]

84. Cartwright GM, Scott B. Redox regulation of an AP-1-like transcription factor, YapA, in the fungal symbiont Epichloe festucae. Eukaryot Cell. 2013; 12:1335-1348. [PubMed: 23893078]

85. Lessing F, Kniemeyer O, Wozniok I, Loeffler J, Kurzai O, Haertl A, Brakhage AA. The Aspergillus fumigatus transcriptional regulator AfYap1 represents the major regulator for defense against reactive oxygen intermediates but is dispensable for pathogenicity in an intranasal mouse infection model. Eukaryot Cell. 2007; 6:2290-2302. [PubMed: 17921349]

86. Paul S, Doering TL, Moye-Rowley WS. Cryptococcus neoformans Yap1 is required for normal fluconazole and oxidative stress resistance. Fungal Genet Biol. 2015; 74:1-9. [PubMed: 25445311]

87. Jain C, Pastor K, Gonzalez AY, Lorenz MC, Rao RP. The role of Candida albicans AP-1 protein against host derived ROS in in vivo models of infection. Virulence. 2013; 4:67-76. [PubMed: 23314569]

88. Guo M, Chen Y, Du Y, Dong Y, Guo W, Zhai S, Zhang H, Dong S, Zhang Z, Wang Y, Wang P, Zheng X. The bZIP transcription factor MoAP1 mediates the oxidative stress response and is critical for pathogenicity of the rice blast fungus Magnaporthe oryzae. PLoS Pathog. 2011; 7:e1001302. [PubMed: 21383978]

89. Molina L, Kahmann R. An Ustilago maydis gene involved in $\mathrm{H}_{2} \mathrm{O}_{2}$ detoxification is required for virulence. Plant Cell. 2007; 19:2293-2309. [PubMed: 17616735]

90. Yu PL, Wang CL, Chen PY, Lee MH. The YAP1 homolog-mediated redox sensing is crucial for a successful infection by Monilinia fructicola. Mol Plant Pathol. 2016; 30:12438.

91. Roetzer A, Klopf E, Gratz N, Marcet-Houben M, Hiller E, Rupp S, Gabaldon T, Kovarik P, Schuller C. Regulation of Candida glabrata oxidative stress resistance is adapted to host environment. FEBS Lett. 2011; 585:319-327. [PubMed: 21156173]

92. Chen D, Wilkinson CR, Watt S, Penkett CJ, Toone WM, Jones N, Bahler J. Multiple pathways differentially regulate global oxidative stress responses in fission yeast. Mol Biol Cell. 2008; 19:308-317. [PubMed: 18003976]

93. Mulford KE, Fassler JS. Association of the Skn7 and Yap1 transcription factors in the Saccharomyces cerevisiae oxidative stress response. Eukaryot Cell. 2011; 10:761-769. [PubMed: 21478431]

94. Quinn J, Malakasi P, Smith DA, Cheetham J, Buck V, Millar JB, Morgan BA. Two-component mediated peroxide sensing and signal transduction in fission yeast. Antioxid Redox Signal. 2011; 15:153-165. [PubMed: 20919928]

95. Fassler JS, West AH. Fungal Skn7 stress responses and their relationship to virulence. Eukaryot Cell. 2011; 10:156-167. [PubMed: 21131436]

96. Wilkinson MG, Samuels M, Takeda T, Toone WM, Shieh JC, Toda T, Millar JB, Jones N. The Atf1 transcription factor is a target for the Sty1 stress-activated MAP kinase pathway in fission yeast. Genes Dev. 1996; 10:2289-2301. [PubMed: 8824588]

97. Lawrence CL, Jones N, Wilkinson CR. Stress-induced phosphorylation of S. pombe Atf1 abrogates its interaction with F box protein Fbh1. Curr Biol. 2009; 19:1907-1911. [PubMed: 19836238]

98. Lawrence CL, Maekawa H, Worthington JL, Reiter W, Wilkinson CR, Jones N. Regulation of Schizosaccharomyces pombe Atf1 protein levels by Sty1-mediated phosphorylation and heterodimerization with Pcr1. J Biol Chem. 2007; 282:5160-5170. [PubMed: 17182615]

99. Missall TA, Lodge JK. Function of the thioredoxin proteins in Cryptococcus neoformans during stress or virulence and regulation by putative transcriptional modulators. Mol Microbiol. 2005; 57:847-858. [PubMed: 16045626]

100. Guo M, Guo W, Chen Y, Dong S, Zhang X, Zhang H, Song W, Wang W, Wang Q, Lv R, Zhang Z, Wang Y, Zheng X. The basic leucine zipper transcription factor Moatf1 mediates oxidative stress responses and is necessary for full virulence of the rice blast fungus Magnaporthe oryzae. Mol Plant Microbe Interact. 2010; 23:1053-1068. [PubMed: 20615116] 
101. Hagiwara D, Suzuki S, Kamei K, Gonoi T, Kawamoto S. The role of AtfA and HOG MAPK pathway in stress tolerance in conidia of Aspergillus fumigatus. Fungal Genet Biol. 2014; 73:138-149. [PubMed: 25459537]

102. Lara-Rojas F, Sanchez O, Kawasaki L, Aguirre J. Aspergillus nidulans transcription factor AtfA interacts with the MAPK SakA to regulate general stress responses, development and spore functions. Mol Microbiol. 2011; 80:436-454. [PubMed: 21320182]

103. Bahn YS, Jung KW. Stress signaling pathways for the pathogenicity of Cryptococcus. Eukaryot Cell. 2013; 12:1564-1577. [PubMed: 24078305]

104. Schuller C, Brewster JL, Alexander MR, Gustin MC, Ruis H. The HOG pathway controls osmotic regulation of transcription via the stress response element (STRE) of the Saccharomyces cerevisiae CTT1 gene. Embo J. 1994; 13:4382-4389. [PubMed: 7523111]

105. Degols G, Shiozaki K, Russell P. Activation and regulation of the Spc1 stress-activated protein kinase in Schizosaccharomyces pombe. Mol Cell Biol. 1996; 16:2870-2877. [PubMed: 8649397]

106. Alonso-Monge R, Navarro-Garcia F, Roman E, Negredo AI, Eisman B, Nombela C, Pla J. The Hog 1 mitogen-activated protein kinase is essential in the oxidative stress response and chlamydospore formation in Candida albicans. Eukaryot Cell. 2003; 2:351-361. [PubMed: 12684384]

107. Du C, Sarfati J, Latge JP, Calderone R. The role of the sakA (Hog1) and tcsB ( $\ln 1)$ genes in the oxidant adaptation of Aspergillus fumigatus. Med Mycol. 2006; 44:211-218. [PubMed: 16702099]

108. Moriwaki A, Kubo E, Arase S, Kihara J. Disruption of SRM1, a mitogen-activated protein kinase gene, affects sensitivity to osmotic and ultraviolet stressors in the phytopathogenic fungus Bipolaris oryzae. FEMS Microbiol Lett. 2006; 257:253-261. [PubMed: 16553861]

109. Zheng D, Zhang S, Zhou X, Wang C, Xiang P, Zheng Q, Xu JR. The FgHOG1 pathway regulates hyphal growth, stress responses, and plant infection in Fusarium graminearum. PLoS One. 2012; 7:e49495. [PubMed: 23166686]

110. Veal EA, Findlay VJ, Day AM, Bozonet SM, Evans JM, Quinn J, Morgan BA. A 2-Cys peroxiredoxin regulates peroxide-induced oxidation and activation of a stress-activated MAP kinase. Mol Cell. 2004; 15:129-139. [PubMed: 15225554]

111. Smith DA, Nicholls S, Morgan BA, Brown AJ, Quinn J. A conserved stress-activated protein kinase regulates a core stress response in the human pathogen Candida albicans. Mol Biol Cell. 2004; 15:4179-4190. [PubMed: 15229284]

112. Li D, Gurkovska V, Sheridan M, Calderone R, Chauhan N. Studies on the regulation of the twocomponent histidine kinase gene $C H K 1$ in Candida albicans using the heterologous lacZ reporter gene. Microbiology (Reading, England). 2004; 150:3305-3313.

113. Furukawa K, Hoshi Y, Maeda T, Nakajima T, Abe K. Aspergillus nidulans HOG pathway is activated only by two-component signalling pathway in response to osmotic stress. Mol Microbiol. 2005; 56:1246-1261. [PubMed: 15882418]

114. Fang FC. Antimicrobial reactive oxygen and nitrogen species: concepts and controversies. Nat Rev Microbiol. 2004; 2:820-832. [PubMed: 15378046]

115. Gross NT, Nessa K, Camner P, Jarstrand C. Production of nitric oxide by rat alveolar macrophages stimulated by Cryptococcus neoformans or Aspergillus fumigatus. Med Mycol. 1999; 37:151-157. [PubMed: 10421846]

116. Nathan C, Shiloh MU. Reactive oxygen and nitrogen intermediates in the relationship between mammalian hosts and microbial pathogens. Proc Natl Acad Sci U S A. 2000; 97:8841-8848. [PubMed: 10922044]

117. Hromatka BS, Noble SM, Johnson AD. Transcriptional response of Candida albicans to nitric oxide and the role of the $Y H B 1$ gene in nitrosative stress and virulence. Mol Biol Cell. 2005; 16:4814-4826. [PubMed: 16030247]

118. Missall TA, Pusateri ME, Donlin MJ, Chambers KT, Corbett JA, Lodge JK. Posttranslational, translational, and transcriptional responses to nitric oxide stress in Cryptococcus neoformans: implications for virulence. Eukaryot Cell. 2006; 5:518-529. [PubMed: 16524907] 
119. Baidya S, Cary JW, Grayburn WS, Calvo AM. Role of nitric oxide and flavohemoglobin homolog genes in Aspergillus nidulans sexual development and mycotoxin production. Appl Environ Microbiol. 2011; 77:5524-5528. [PubMed: 21642398]

120. Prats E, Carver TL, Mur LA. Pathogen-derived nitric oxide influences formation of the appressorium infection structure in the phytopathogenic fungus Blumeria graminis. Res Microbiol. 2008; 159:476-480. [PubMed: 18554873]

121. Zhang Z, Wang J, Chai R, Qiu H, Jiang H, Mao X, Wang Y, Liu F, Sun G. An S(hydroxymethyl)glutathione dehydrogenase is involved in conidiation and full virulence in the rice blast fungus Magnaporthe oryzae. PLoS One. 2015; 10:e0120627. [PubMed: 25793615]

122. Arasimowicz-Jelonek M, Floryszak-Wieczorek J. Nitric Oxide in the Offensive Strategy of Fungal and Oomycete Plant Pathogens. Front Plant Sci. 2016; 7:252. [PubMed: 26973690]

123. Grant CM, Collinson LP, Roe JH, Dawes IW. Yeast glutathione reductase is required for protection against oxidative stress and is a target gene for yAP-1 transcriptional regulation. Mol Microbiol. 1996; 21:171-179. [PubMed: 8843443]

124. Liu L, Hausladen A, Zeng M, Que L, Heitman J, Stamler JS. A metabolic enzyme for Snitrosothiol conserved from bacteria to humans. Nature. 2001; 410:490-494. [PubMed: 11260719]

125. Tillmann AT, Strijbis K, Cameron G, Radmaneshfar E, Thiel M, Munro CA, MacCallum DM, Distel B, Gow NA, Brown AJ. Contribution of Fdh3 and Glr1 to Glutathione Redox State, Stress Adaptation and Virulence in Candida albicans. PLoS One. 2015; 10:e0126940. [PubMed: 26039593]

126. Tillmann A, Gow NA, Brown AJ. Nitric oxide and nitrosative stress tolerance in yeast. Biochem Soc Trans. 2011; 39:219-223. [PubMed: 21265777]

127. Sarver A, DeRisi J. Fzf1p regulates an inducible response to nitrosative stress in Saccharomyces cerevisiae. Mol Biol Cell. 2005; 16:4781-4791. [PubMed: 16014606]

128. Chiranand W, McLeod I, Zhou H, Lynn JJ, Vega LA, Myers H, Yates JR 3rd, Lorenz MC, Gustin MC. CTA4 transcription factor mediates induction of nitrosative stress response in Candida albicans. Eukaryot Cell. 2008; 7:268-278. [PubMed: 18083829]

129. Ullmann BD, Myers H, Chiranand W, Lazzell AL, Zhao Q, Vega LA, Lopez-Ribot JL, Gardner PR, Gustin MC. Inducible defense mechanism against nitric oxide in Candida albicans. Eukaryot Cell. 2004; 3:715-723. [PubMed: 15189992]

130. de Jesus-Berrios M, Liu L, Nussbaum JC, Cox GM, Stamler JS, Heitman J. Enzymes that counteract nitrosative stress promote fungal virulence. Curr Biol. 2003; 13:1963-1968. [PubMed: 14614821]

131. Levin DE. Cell wall integrity signaling in Saccharomyces cerevisiae. Microbiol Mol Biol Rev. 2005; 69:262-291. [PubMed: 15944456]

132. Xie X, Lipke PN. On the evolution of fungal and yeast cell walls. Yeast. 2010; 27:479-488. [PubMed: 20641026]

133. Erwig LP, Gow NA. Interactions of fungal pathogens with phagocytes. Nat Rev Microbiol. 2016; 14:163-176. [PubMed: 26853116]

134. Roemer T, Krysan DJ. Antifungal drug development: challenges, unmet clinical needs, and new approaches. Cold Spring Harb Perspect Med. 2014; 4

135. Munro CA. Chitin and glucan, the yin and yang of the fungal cell wall, implications for antifungal drug discovery and therapy. Adv Appl Microbiol. 2013; 83:145-172. [PubMed: 23651596]

136. Walker LA, Gow NA, Munro CA. Elevated chitin content reduces the susceptibility of Candida species to caspofungin. Antimicrob Agents Chemother. 2013; 57:146-154. [PubMed: 23089748]

137. Walker LA, Munro CA, de Bruijn I, Lenardon MD, McKinnon A, Gow NA. Stimulation of chitin synthesis rescues Candida albicans from echinocandins. PLoS Pathog. 2008; 4:e1000040. [PubMed: 18389063]

138. Cowen LE. The fungal Achilles' heel: targeting Hsp90 to cripple fungal pathogens. Curr Opin Microbiol. 2013; 16:377-384. [PubMed: 23588026]

139. Singh SD, Robbins N, Zaas AK, Schell WA, Perfect JR, Cowen LE. Hsp90 governs echinocandin resistance in the pathogenic yeast Candida albicans via calcineurin. PLoS Pathog. 2009; 5:e1000532. [PubMed: 19649312] 
140. LaFayette SL, Collins C, Zaas AK, Schell WA, Betancourt-Quiroz M, Gunatilaka AA, Perfect JR, Cowen LE. PKC signaling regulates drug resistance of the fungal pathogen Candida albicans via circuitry comprised of Mkc1, calcineurin, and Hsp90. PLoS Pathog. 2010; 6:e1001069. [PubMed: 20865172]

141. Millson SH, Truman AW, King V, Prodromou C, Pearl LH, Piper PW. A two-hybrid screen of the yeast proteome for Hsp90 interactors uncovers a novel Hsp90 chaperone requirement in the activity of a stress-activated mitogen-activated protein kinase, Slt2p (Mpk1p). Eukaryot Cell. 2005; 4:849-860. [PubMed: 15879519]

142. Truman AW, Millson SH, Nuttall JM, Mollapour M, Prodromou C, Piper PW. In the yeast heat shock response, Hsf1-directed induction of Hsp90 facilitates the activation of the Slt2 (Mpk1) mitogen-activated protein kinase required for cell integrity. Eukaryot Cell. 2007; 6:744-752. [PubMed: 17293484]

143. Munro CA, Selvaggini S, de Bruijn I, Walker L, Lenardon MD, Gerssen B, Milne S, Brown AJ, Gow NA. The PKC, HOG and Ca2+ signalling pathways co-ordinately regulate chitin synthesis in Candida albicans. Mol Microbiol. 2007; 63:1399-1413. [PubMed: 17302816]

144. Dichtl K, Samantaray S, Wagener J. Cell wall integrity signalling in human pathogenic fungi. Cell Microbiol. 2016; 18:1228-1238. [PubMed: 27155139]

145. Lamoth F, Juvvadi PR, Steinbach WJ. Heat shock protein 90 (Hsp90): A novel antifungal target against Aspergillus fumigatus. Crit Rev Microbiol. 2016; 42:310-321. [PubMed: 25243616]

146. Ortiz-Urquiza A, Keyhani NO. Stress response signaling and virulence: insights from entomopathogenic fungi. Curr Genet. 2015; 61:239-249. [PubMed: 25113413]

147. Valiante V, Macheleidt J, Foge M, Brakhage AA. The Aspergillus fumigatus cell wall integrity signaling pathway: drug target, compensatory pathways, and virulence. Front Microbiol. 2015; 6:325. [PubMed: 25932027]

148. Juvvadi PR, Lee SC, Heitman J, Steinbach WJ. Calcineurin in fungal virulence and drug resistance: Prospects for harnessing targeted inhibition of calcineurin for an antifungal therapeutic approach. Virulence. 2016; 20:1-12.

149. Hast MA, Nichols CB, Armstrong SM, Kelly SM, Hellinga HW, Alspaugh JA, Beese LS. Structures of Cryptococcus neoformans protein farnesyltransferase reveal strategies for developing inhibitors that target fungal pathogens. J Biol Chem. 2011; 286:35149-35162. [PubMed: 21816822]

150. Robbins N, Spitzer M, Yu T, Cerone RP, Averette AK, Bahn YS, Heitman J, Sheppard DC, Tyers M, Wright GD. An Antifungal Combination Matrix Identifies a Rich Pool of Adjuvant Molecules that Enhance Drug Activity against Diverse Fungal Pathogens. Cell Rep. 2015; 13:1481-1492. [PubMed: 26549450]

151. Cyert MS, Philpott CC. Regulation of cation balance in Saccharomyces cerevisiae. Genetics. 2013; 193:677-713. [PubMed: 23463800]

152. Serrano R, Bernal D, Simon E, Arino J. Copper and iron are the limiting factors for growth of the yeast Saccharomyces cerevisiae in an alkaline environment. J Biol Chem. 2004; 279:1969819704. [PubMed: 14993228]

153. Davis DA. How human pathogenic fungi sense and adapt to $\mathrm{pH}$ : the link to virulence. Curr Opin Microbiol. 2009; 12:365-370. [PubMed: 19632143]

154. Penalva MA, Lucena-Agell D, Arst HN Jr. Liaison alcaline: Pals entice non-endosomal ESCRTs to the plasma membrane for $\mathrm{pH}$ signaling. Curr Opin Microbiol. 2014; 22:49-59. [PubMed: 25460796]

155. Li W, Mitchell AP. Proteolytic activation of Rim1p, a positive regulator of yeast sporulation and invasive growth. Genetics. 1997; 145:63-73. [PubMed: 9017390]

156. Tilburn J, Sarkar S, Widdick DA, Espeso EA, Orejas M, Mungroo J, Penalva MA, Arst HN Jr. The Aspergillus PacC zinc finger transcription factor mediates regulation of both acid- and alkaline-expressed genes by ambient pH. Embo J. 1995; 14:779-790. [PubMed: 7882981]

157. Galindo A, Calcagno-Pizarelli AM, Arst HN Jr, Penalva MA. An ordered pathway for the assembly of fungal ESCRT-containing ambient $\mathrm{pH}$ signalling complexes at the plasma membrane. J Cell Sci. 2012; 125:1784-1795. [PubMed: 22344261] 
158. Herrador A, Herranz S, Lara D, Vincent O. Recruitment of the ESCRT machinery to a putative seven-transmembrane-domain receptor is mediated by an arrestin-related protein. Mol Cell Biol. 2010; 30:897-907. [PubMed: 20028738]

159. Hervas-Aguilar A, Galindo A, Penalva MA. Receptor-independent Ambient pH signaling by ubiquitin attachment to fungal arrestin-like PalF. J Biol Chem. 2010; 285:18095-18102. [PubMed: 20368671]

160. Obara K, Yamamoto H, Kihara A. Membrane protein Rim21 plays a central role in sensing ambient pH in Saccharomyces cerevisiae. J Biol Chem. 2012; 287:38473-38481. [PubMed: 23019326]

161. Nishino K, Obara K, Kihara A. The C-terminal Cytosolic Region of Rim21 Senses Alterations in Plasma Membrane Lipid Composition: INSIGHTS INTO SENSING MECHANISMS FOR PLASMA MEMBRANE LIPID ASYMMETRY. J Biol Chem. 2015; 290:30797-30805. [PubMed: 26527678]

162. De Bernardis F, Muhlschlegel FA, Cassone A, Fonzi WA. The $\mathrm{pH}$ of the host niche controls gene expression in and virulence of Candida albicans. Infect Immun. 1998; 66:3317-3325. [PubMed: 9632601]

163. El Barkani A, Kurzai O, Fonzi WA, Ramon A, Porta A, Frosch M, Muhlschlegel FA. Dominant active alleles of RIM101 (PRR2) bypass the $\mathrm{pH}$ restriction on filamentation of Candida albicans. Mol Cell Biol. 2000; 20:4635-4647. [PubMed: 10848590]

164. Bertuzzi M, Schrettl M, Alcazar-Fuoli L, Cairns TC, Munoz A, Walker LA, Herbst S, Safari M, Cheverton AM, Chen D, Liu H, Saijo S, Fedorova ND, Armstrong-James D, Munro CA, Read ND, Filler SG, Espeso EA, Nierman WC, Haas H, Bignell EM. The pH-responsive PacC transcription factor of Aspergillus fumigatus governs epithelial entry and tissue invasion during pulmonary aspergillosis. PLoS Pathog. 2014; 10:e1004413. [PubMed: 25329394]

165. Ortoneda M, Guarro J, Madrid MP, Caracuel Z, Roncero MI, Mayayo E, Di Pietro A. Fusarium oxysporum as a multihost model for the genetic dissection of fungal virulence in plants and mammals. Infect Immun. 2004; 72:1760-1766. [PubMed: 14977985]

166. O'Meara TR, Norton D, Price MS, Hay C, Clements MF, Nichols CB, Alspaugh JA. Interaction of Cryptococcus neoformans Rim101 and protein kinase A regulates capsule. PLoS Pathog. 2010; 6:e1000776. [PubMed: 20174553]

167. Ost KS, O'Meara TR, Huda N, Esher SK, Alspaugh JA. The Cryptococcus neoformans alkaline response pathway: identification of a novel rim pathway activator. PLoS Genet. 2015; 11:e1005159. [PubMed: 25859664]

168. Huang W, Shang Y, Chen P, Gao Q, Wang C. MrpacC regulates sporulation, insect cuticle penetration and immune evasion in Metarhizium robertsii. Environ Microbiol. 2015; 17:9941008. [PubMed: 24612440]

169. Zou CG, Tu HH, Liu XY, Tao N, Zhang KQ. PacC in the nematophagous fungus Clonostachys rosea controls virulence to nematodes. Environ Microbiol. 2010; 12:1868-1877. [PubMed: 20236165]

170. Caracuel Z, Roncero MI, Espeso EA, Gonzalez-Verdejo CI, Garcia-Maceira FI, Di Pietro A. The $\mathrm{pH}$ signalling transcription factor PacC controls virulence in the plant pathogen Fusarium oxysporum. Mol Microbiol. 2003; 48:765-779. [PubMed: 12694620]

171. Landraud P, Chuzeville S, Billon-Grande G, Poussereau N, Bruel C. Adaptation to $\mathrm{pH}$ and role of PacC in the rice blast fungus Magnaporthe oryzae. PLoS One. 2013; 8:e69236. [PubMed: 23874922]

172. Zhang T, Sun X, Xu Q, Candelas LG, Li H. The $\mathrm{pH}$ signaling transcription factor PacC is required for full virulence in Penicillium digitatum. Appl Microbiol Biotechnol. 2013; 97:90879098. [PubMed: 23917633]

173. Juvvadi PR, Gehrke C, Fortwendel JR, Lamoth F, Soderblom EJ, Cook EC, Hast MA, Asfaw YG, Moseley MA, Creamer TP, Steinbach WJ. Phosphorylation of Calcineurin at a novel serineproline rich region orchestrates hyphal growth and virulence in Aspergillus fumigatus. PLoS Pathog. 2013; 9:e1003564. [PubMed: 23990785]

174. Odom A, Muir S, Lim E, Toffaletti DL, Perfect J, Heitman J. Calcineurin is required for virulence of Cryptococcus neoformans. Embo J. 1997; 16:2576-2589. [PubMed: 9184205] 
175. Schumacher J, Viaud M, Simon A, Tudzynski B. The Galpha subunit BCG1, the phospholipase C (BcPLC1) and the calcineurin phosphatase co-ordinately regulate gene expression in the grey mould fungus Botrytis cinerea. Mol Microbiol. 2008; 67:1027-1050. [PubMed: 18208491]

176. Serrano R, Ruiz A, Bernal D, Chambers JR, Arino J. The transcriptional response to alkaline pH in Saccharomyces cerevisiae: evidence for calcium-mediated signalling. Mol Microbiol. 2002; 46:1319-1333. [PubMed: 12453218]

177. Spielvogel A, Findon H, Arst HN, Araujo-Bazan L, Hernandez-Ortiz P, Stahl U, Meyer V, Espeso EA. Two zinc finger transcription factors, CrzA and SltA, are involved in cation homoeostasis and detoxification in Aspergillus nidulans. Biochem J. 2008; 414:419-429. [PubMed: 18471095]

178. Stathopoulos AM, Cyert MS. Calcineurin acts through the CRZ1/TCN1-encoded transcription factor to regulate gene expression in yeast. Genes Dev. 1997; 11:3432-3444. [PubMed: 9407035]

179. Zacchi LF, Gomez-Raja J, Davis DA. Mds3 regulates morphogenesis in Candida albicans through the TOR pathway. Mol Cell Biol. 2010; 30:3695-3710. [PubMed: 20457806]

180. Serrano R, Martin H, Casamayor A, Arino J. Signaling alkaline $\mathrm{pH}$ stress in the yeast Saccharomyces cerevisiae through the Wsc1 cell surface sensor and the Slt2 MAPK pathway. J Biol Chem. 2006; 281:39785-39795. [PubMed: 17088254]

181. Mellado L, Arst HN Jr, Espeso EA. Proteolytic activation of both components of the cation stressresponsive Slt pathway in Aspergillus nidulans. Mol Biol Cell. 2016; 27:2598-2612. [PubMed: 27307585]

182. Mollapour M, Piper PW. Hog1 mitogen-activated protein kinase phosphorylation targets the yeast Fps1 aquaglyceroporin for endocytosis, thereby rendering cells resistant to acetic acid. Mol Cell Biol. 2007; 27:6446-6456. [PubMed: 17620418]

183. Stratford M, Nebe-von-Caron G, Steels H, Novodvorska M, Ueckert J, Archer DB. Weak-acid preservatives: $\mathrm{pH}$ and proton movements in the yeast Saccharomyces cerevisiae. Int J Food Microbiol. 2013; 161:164-171. [PubMed: 23334094]

184. Stratford M, Plumridge A, Nebe-von-Caron G, Archer DB. Inhibition of spoilage mould conidia by acetic acid and sorbic acid involves different modes of action, requiring modification of the classical weak-acid theory. Int J Food Microbiol. 2009; 136:37-43. [PubMed: 19846233]

185. Piper P, Calderon CO, Hatzixanthis K, Mollapour M. Weak acid adaptation: the stress response that confers yeasts with resistance to organic acid food preservatives. Microbiology. 2001; 147:2635-2642. [PubMed: 11577142]

186. Piper P, Mahe Y, Thompson S, Pandjaitan R, Holyoak C, Egner R, Muhlbauer M, Coote P, Kuchler K. The pdr12 ABC transporter is required for the development of weak organic acid resistance in yeast. Embo J. 1998; 17:4257-4265. [PubMed: 9687494]

187. Holyoak CD, Stratford M, McMullin Z, Cole MB, Crimmins K, Brown AJ, Coote PJ. Activity of the plasma membrane $\mathrm{H}(+)$-ATPase and optimal glycolytic flux are required for rapid adaptation and growth of Saccharomyces cerevisiae in the presence of the weak-acid preservative sorbic acid. Appl Environ Microbiol. 1996; 62:3158-3164. [PubMed: 8795204]

188. Ullah A, Orij R, Brul S, Smits GJ. Quantitative analysis of the modes of growth inhibition by weak organic acids in Saccharomyces cerevisiae. Appl Environ Microbiol. 2012; 78:8377-8387. [PubMed: 23001666]

189. Mira NP, Palma M, Guerreiro JF, Sa-Correia I. Genome-wide identification of Saccharomyces cerevisiae genes required for tolerance to acetic acid. Microb Cell Fact. 2010; 9:79. [PubMed: 20973990]

190. Kren A, Mamnun YM, Bauer BE, Schuller C, Wolfger H, Hatzixanthis K, Mollapour M, Gregori C, Piper P, Kuchler K. War1p, a novel transcription factor controlling weak acid stress response in yeast. Mol Cell Biol. 2003; 23:1775-1785. [PubMed: 12588995]

191. Schuller C, Mamnun YM, Mollapour M, Krapf G, Schuster M, Bauer BE, Piper PW, Kuchler K. Global phenotypic analysis and transcriptional profiling defines the weak acid stress response regulon in Saccharomyces cerevisiae. Mol Biol Cell. 2004; 15:706-720. [PubMed: 14617816]

192. Jandric Z, Gregori C, Klopf E, Radolf M, Schuller C. Sorbic acid stress activates the Candida glabrata high osmolarity glycerol MAP kinase pathway. Front Microbiol. 2013; 4:350. [PubMed: 24324463] 
193. Lebel K, MacPherson S, Turcotte B. New tools for phenotypic analysis in Candida albicans: the WAR1 gene confers resistance to sorbate. Yeast. 2006; 23:249-259. [PubMed: 16544288]

194. Ramsdale M, Selway L, Stead D, Walker J, Yin Z, Nicholls SM, Crowe J, Sheils EM, Brown AJ. MNL1 regulates weak acid-induced stress responses of the fungal pathogen Candida albicans. Mol Biol Cell. 2008; 19:4393-4403. [PubMed: 18653474]

195. Stratford M, Steels H, Nebe-von-Caron G, Novodvorska M, Hayer K, Archer DB. Extreme resistance to weak-acid preservatives in the spoilage yeast Zygosaccharomyces bailii. Int J Food Microbiol. 2013; 166:126-134. [PubMed: 23856006]

196. Mager WH, De Kruijff AJ. Stress-induced transcriptional activation. Microbiol Rev. 1995; 59:506-531. [PubMed: 7565416]

197. Gorner W, Durchschlag E, Martinez-Pastor MT, Estruch F, Ammerer G, Hamilton B, Ruis H, Schuller C. Nuclear localization of the $\mathrm{C} 2 \mathrm{H} 2$ zinc finger protein Msn2p is regulated by stress and protein kinase A activity. Genes Dev. 1998; 12:586-597. [PubMed: 9472026]

198. Gorner W, Durchschlag E, Wolf J, Brown EL, Ammerer G, Ruis H, Schuller C. Acute glucose starvation activates the nuclear localization signal of a stress-specific yeast transcription factor. Embo J. 2002; 21:135-144. [PubMed: 11782433]

199. Petrenko N, Chereji RV, McClean MN, Morozov AV, Broach JR. Noise and interlocking signaling pathways promote distinct transcription factor dynamics in response to different stresses. Mol Biol Cell. 2013; 24:2045-2057. [PubMed: 23615444]

200. Gasch AP, Huang M, Metzner S, Botstein D, Elledge SJ, Brown PO. Genomic expression responses to DNA-damaging agents and the regulatory role of the yeast ATR homolog Mec1p. Mol Biol Cell. 2001; 12:2987-3003. [PubMed: 11598186]

201. Nicholls S, Straffon M, Enjalbert B, Nantel A, Macaskill S, Whiteway M, Brown AJ. Msn2- and Msn4-like transcription factors play no obvious roles in the stress responses of the fungal pathogen Candida albicans. Eukaryot Cell. 2004; 3:1111-1123. [PubMed: 15470239]

202. Smith DA, Morgan BA, Quinn J. Stress signalling to fungal stress-activated protein kinase pathways. Fems Microbiology Letters. 2010; 306:1-8. [PubMed: 20345377]

203. Lewis JG, Learmonth RP, Watson K. Induction of heat, freezing and salt tolerance by heat and salt shock in Saccharomyces cerevisiae. Microbiology. 1995; 141(Pt 3):687-694. [PubMed: 7711907]

204. Berry DB, Gasch AP. Stress-activated genomic expression changes serve a preparative role for impending stress in yeast. Mol Biol Cell. 2008; 19:4580-4587. [PubMed: 18753408]

205. Berry DB, Guan Q, Hose J, Haroon S, Gebbia M, Heisler LE, Nislow C, Giaever G, Gasch AP. Multiple means to the same end: the genetic basis of acquired stress resistance in yeast. PLoS Genet. 2011; 7:e1002353. [PubMed: 22102822]

206. Mitchell A, Pilpel Y. A mathematical model for adaptive prediction of environmental changes by microorganisms. Proc Natl Acad Sci U S A. 2011; 108:7271-7276. [PubMed: 21487001]

207. Mitchell A, Romano GH, Groisman B, Yona A, Dekel E, Kupiec M, Dahan O, Pilpel Y. Adaptive prediction of environmental changes by microorganisms. Nature. 2009; 460:220-224. [PubMed: 19536156]

208. Brown AJ, Budge S, Kaloriti D, Tillmann A, Jacobsen MD, Yin Z, Ene IV, Bohovych I, Sandai D, Kastora S, Potrykus J, Ballou ER, Childers DS, Shahana S, Leach MD. Stress adaptation in a pathogenic fungus. J Exp Biol. 2014; 217:144-155. [PubMed: 24353214]

209. Brunke S, Hube B. Adaptive prediction as a strategy in microbial infections. PLoS Pathog. 2014; 10:e1004356. [PubMed: 25275642]

210. Rodaki A, Bohovych IM, Enjalbert B, Young T, Odds FC, Gow NA, Brown AJ. Glucose promotes stress resistance in the fungal pathogen Candida albicans. Mol Biol Cell. 2009; 20:4845-4855. [PubMed: 19759180]

211. Kaloriti D, Jacobsen M, Yin Z, Patterson M, Tillmann A, Smith DA, Cook E, You T, Grimm MJ, Bohovych I, Grebogi C, Segal BH, Gow NA, Haynes K, Quinn J, Brown AJ. Mechanisms underlying the exquisite sensitivity of Candida albicans to combinatorial cationic and oxidative stress that enhances the potent fungicidal activity of phagocytes. MBio. 2014; 5:e1334-01314. [PubMed: 25028425] 
212. Kaloriti D, Tillmann A, Cook E, Jacobsen M, You T, Lenardon M, Ames L, Barahona M, Chandrasekaran K, Coghill G, Goodman D, Gow NA, Grebogi C, Ho HL, Ingram P, McDonagh A, de Moura AP, Pang W, Puttnam M, Radmaneshfar E, Romano MC, Silk D, Stark J, Stumpf M, Thiel M, Thorne T, Usher J, Yin Z, Haynes K, Brown AJ. Combinatorial stresses kill pathogenic Candida species. Med Mycol. 2012; 50:699-709. [PubMed: 22463109]

213. Reeves EP, Lu H, Jacobs HL, Messina CG, Bolsover S, Gabella G, Potma EO, Warley A, Roes J, Segal AW. Killing activity of neutrophils is mediated through activation of proteases by $\mathrm{K}+$ flux. Nature. 2002; 416:291-297. [PubMed: 11907569]

214. Wang Y, Cao YY, Jia XM, Cao YB, Gao PH, Fu XP, Ying K, Chen WS, Jiang YY. Cap1p is involved in multiple pathways of oxidative stress response in Candida albicans. Free Radic Biol Med. 2006; 40:1201-1209. [PubMed: 16545688]

215. Kos I, Patterson MJ, Znaidi S, Kaloriti D, da Silva Dantas A, Herrero-de-Dios CM, d'Enfert C, Brown AJ, Quinn J. Mechanisms Underlying the Delayed Activation of the Cap1 Transcription Factor in Candida albicans following Combinatorial Oxidative and Cationic Stress Important for Phagocytic Potency. MBio. 2016; 7:e00331. [PubMed: 27025253]

216. Enjalbert B, MacCallum DM, Odds FC, Brown AJ. Niche-specific activation of the oxidative stress response by the pathogenic fungus Candida albicans. Infection and Immunity. 2007; 75:2143-2151. [PubMed: 17339352]

217. Francois J, Parrou JL. Reserve carbohydrates metabolism in the yeast Saccharomyces cerevisiae. FEMS Microbiol Rev. 2001; 25:125-145. [PubMed: 11152943]

218. Grant CM. Role of the glutathione/glutaredoxin and thioredoxin systems in yeast growth and response to stress conditions. Mol Microbiol. 2001; 39:533-541. [PubMed: 11169096]

219. Nwaka S, Holzer H. Molecular biology of trehalose and the trehalases in the yeast Saccharomyces cerevisiae. Prog Nucleic Acid Res Mol Biol. 1998; 58:197-237. [PubMed: 9308367]

220. Wiemken A. Trehalose in yeast, stress protectant rather than reserve carbohydrate. Antonie Van Leeuwenhoek. 1990; 58:209-217. [PubMed: 2256682]

221. Peralta D, Bronowska AK, Morgan B, Doka E, Van Laer K, Nagy P, Grater F, Dick TP. A proton relay enhances $\mathrm{H}_{2} \mathrm{O}_{2}$ sensitivity of GAPDH to facilitate metabolic adaptation. Nat Chem Biol. 2015; 11:156-163. [PubMed: 25580853]

222. Ralser M, Wamelink MM, Latkolik S, Jansen EE, Lehrach H, Jakobs C. Metabolic reconfiguration precedes transcriptional regulation in the antioxidant response. Nat Biotechnol. 2009; 27:604-605. [PubMed: 19587661]

223. Komalapriya C, Kaloriti D, Tillmann AT, Yin Z, Herrero-de-Dios C, Jacobsen MD, Belmonte RC, Cameron G, Haynes K, Grebogi C, de Moura AP, Gow NA, Thiel M, Quinn J, Brown AJ, Romano MC. Integrative Model of Oxidative Stress Adaptation in the Fungal Pathogen Candida albicans. PLoS One. 2015; 10:e0137750. [PubMed: 26368573]

224. Schaber J, Adrover MA, Eriksson E, Pelet S, Petelenz-Kurdziel E, Klein D, Posas F, Goksor M, Peter M, Hohmann S, Klipp E. Biophysical properties of Saccharomyces cerevisiae and their relationship with HOG pathway activation. Eur Biophys J. 2010; 39:1547-1556. [PubMed: 20563574]

225. Leach MD, Tyc KM, Brown AJ, Klipp E. Modelling the regulation of thermal adaptation in Candida albicans, a major fungal pathogen of humans. PLoS One. 2012; 7:e32467. [PubMed: 22448221]

226. Garreau H, Hasan RN, Renault G, Estruch F, Boy-Marcotte E, Jacquet M. Hyperphosphorylation of Msn2p and Msn4p in response to heat shock and the diauxic shift is inhibited by cAMP in Saccharomyces cerevisiae. Microbiology. 2000; 146(Pt 9):2113-2120. [PubMed: 10974099]

227. Alepuz PM, Cunningham KW, Estruch F. Glucose repression affects ion homeostasis in yeast through the regulation of the stress-activated ENA1 gene. Mol Microbiol. 1997; 26:91-98. [PubMed: 9383192]

228. Stanhill A, Schick N, Engelberg D. The yeast ras/cyclic AMP pathway induces invasive growth by suppressing the cellular stress response. Mol Cell Biol. 1999; 19:7529-7538. [PubMed: 10523641] 
229. Ene IV, Adya AK, Wehmeier S, Brand AC, Maccallum DM, Gow NA, Brown AJ. Host carbon sources modulate cell wall architecture, drug resistance and virulence in a fungal pathogen. Cell Microbiol. 2012; 14:1319-1335. [PubMed: 22587014] 


\section{CHAPTER SUMMARY}

Fungal species display an extraordinarily diverse range of lifestyles. Nevertheless, the survival of each species depends on its ability to sense and respond to changes in its natural environment. Environmental changes such as fluctuations in temperature, water balance or $\mathrm{pH}$, or exposure to chemical insults such as reactive oxygen and nitrogen species, exert stresses that perturb cellular homeostasis and cause molecular damage to the fungal cell. Consequently, fungi have evolved mechanisms to repair this damage, detoxify chemical insults, and restore cellular homeostasis. Most stresses are fundamental in nature and consequently, there has been significant evolutionary conservation in the nature of the resultant responses across the fungal kingdom and beyond. For example, heat shock generally induces the synthesis of chaperones that promote protein refolding, antioxidants are generally synthesized in response to an oxidative stress, and osmolyte levels are generally increased following a hyper-osmotic shock. In this chapter we summarize the current understanding of these and other stress responses as well as the signaling pathways that regulate them in the fungi. Model yeasts such as Saccharomyces cerevisiae are compared with filamentous fungi, as well as with pathogens of plants and humans. We also discuss current challenges associated with defining the dynamics of stress responses and with the elaboration of fungal stress adaptation under conditions that reflect natural environments in which fungal cells may be exposed to different types of stresses, either sequentially or simultaneously. 


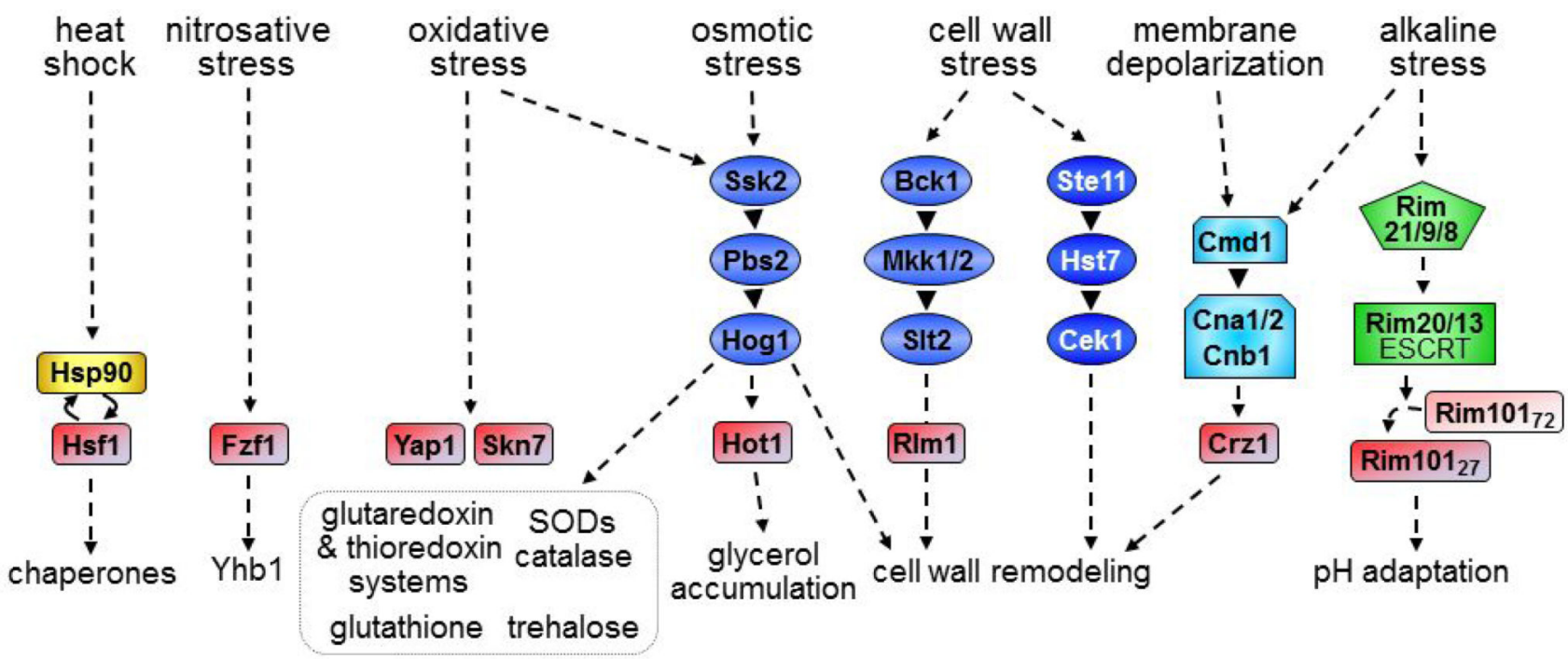

Figure 1. Cartoon summarizing stress pathways in the model fungus S. cerevisiae See text. This figure summarizes some, but not all, of the known components of these signalling pathways. Components of MAP kinase signalling modules are highlighted in blue, transcription factors in pink, components of the calmodulin-calcineurin pathway in cyan, Rim pathway components in green, and the molecular chaperone Hsp90 in yellow. Note the C. albicans Cek1 MAPK pathway, which contributes to cell wall remodelling in this fungus, is included (dark blue ovals with white lettering). 
A.

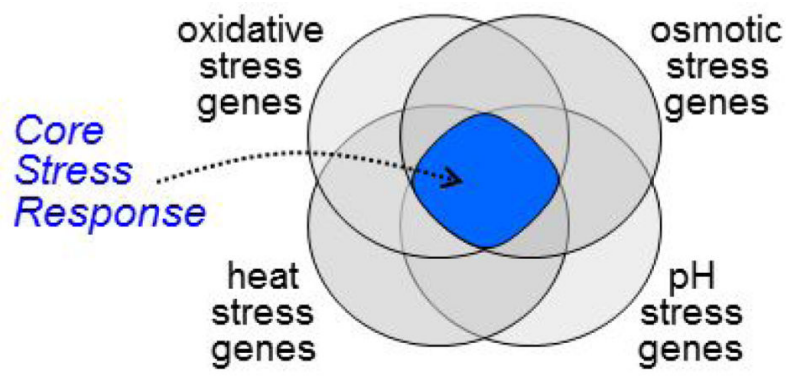

B. Sequential stresses
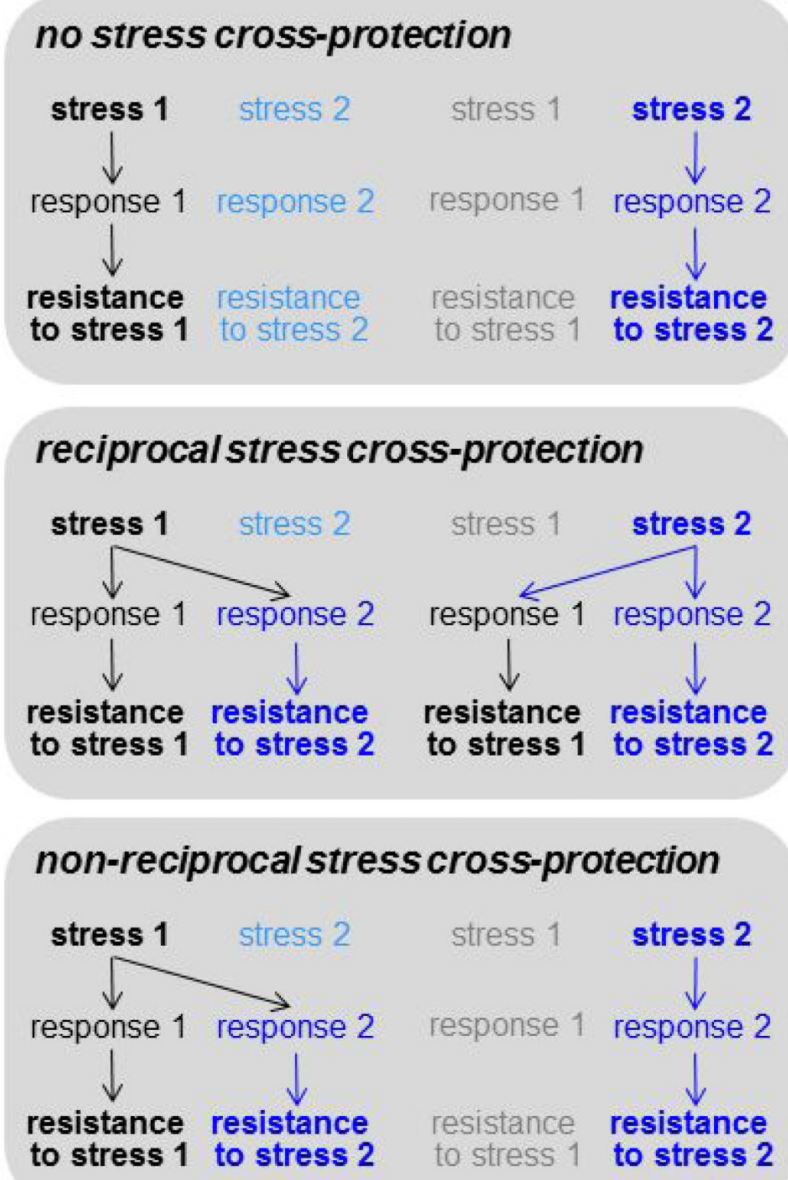

Figure 2. The Core Stress Response can lead to stress cross-protection

A. Core Stress Responses, which have been defined by genome-wide transcriptional profiling, represent the set of genes that is commonly up- or down-regulated by different types of stress (see text). This Venn Diagram illustrates the conceptual overlap between these sets of genes, highlighting the Core Stress genes. B. A Core Stress Response can lead to stress cross-protection during exposure to sequential stresses, i.e. cells that are exposed to one type of stress can then display elevated resistance to a subsequent stress of a different type (see text). In some cases no cross-protection is observed. In other cases it is observed, 
but this cross-protection can be reciprocal or non-reciprocal. This can depend on the nature and dose of the initial and subsequent stress. 


\section{Simultaneous stresses}

\section{additive responses}

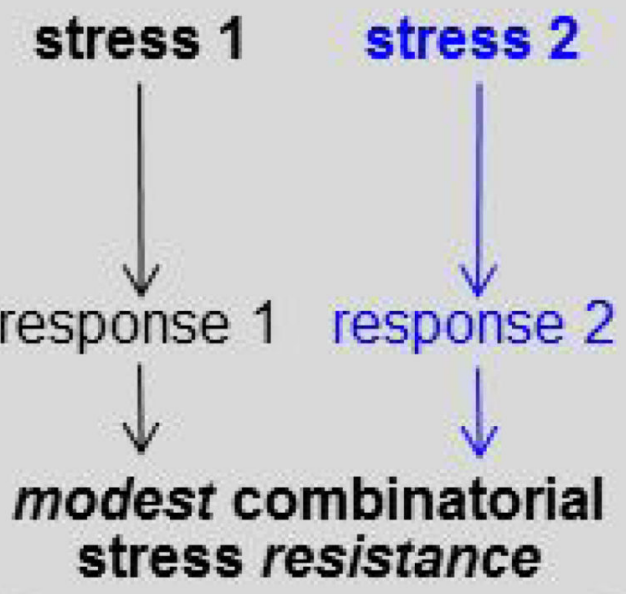

\section{non-additive responses} stress pathway interference
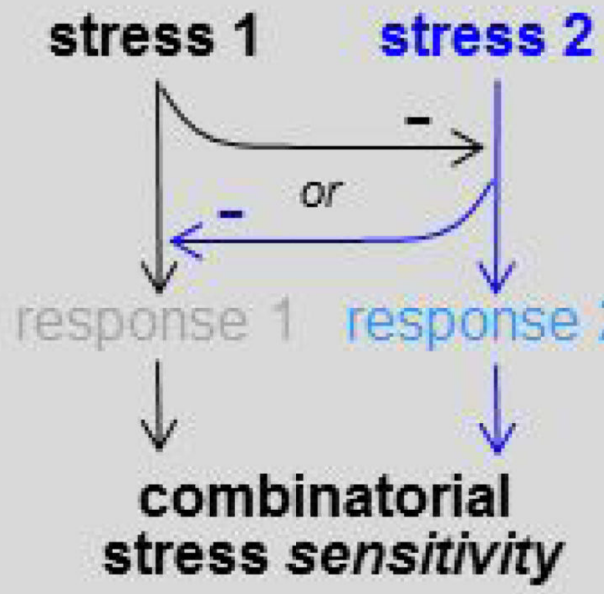

Figure 3. Exposure to combinatorial stresses can yield non-additive outputs

Simultaneous exposure to some combinations of stress (i.e. certain combinatorial stresses) can yield additive outputs if there are no significant interactions between the stress pathways that mediate these responses. However, for some combinatorial stresses (see text), stress pathway interference can block the normal response to one of the imposed stresses, leading to combinatorial stress sensitivity. We are unaware of any examples of the opposite effect, where stress pathway enhancement might lead to elevated levels of combinatorial stress resistance. 


\section{stress}

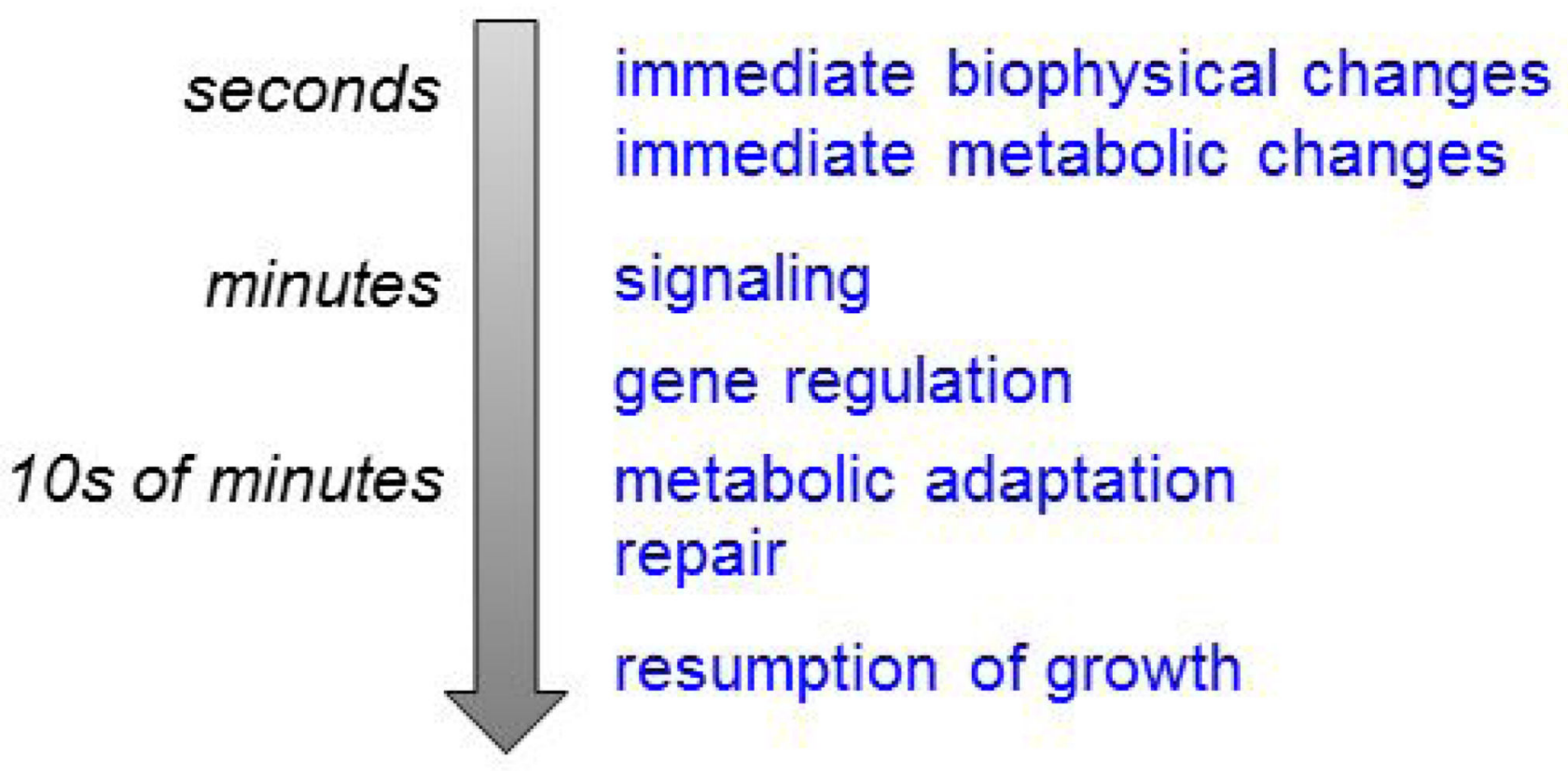

recovery

Figure 4. Different aspects of stress adaptation occur over different timescales

This generic figure summarizes this principle for an environmental insult such as osmotic stress (see text). However, some stresses may include adaptation mechanisms that occur over other timescales. 